OAK RIDGE

NATIONAL LABORATORY

MANAGED BY UT-BATTELLE

FOR THE DEPARTMENT OF ENERGY

\title{
Establishing Specifications for Low Enriched Uranium Fuel Operations \\ Conducted Outside the High Flux Isotope Reactor Site
}

September 2010

\author{
R. T. Primm, III \\ D. L. Pinkston \\ J. D. Sease \\ D. G. Renfro
}

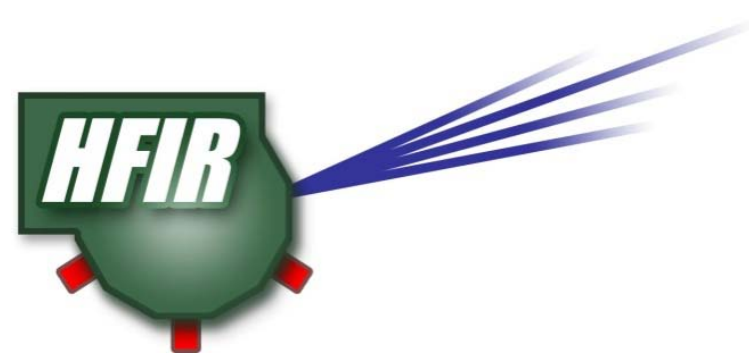




\section{DOCUMENT AVAILABILITY}

Reports produced after January 1, 1996, are generally available free via the U.S. Department of Energy (DOE) Information Bridge.

Web site http://www.osti.gov/bridge

Reports produced before January 1, 1996, may be purchased by members of the public from the following source.

National Technical Information Service

5285 Port Royal Road

Springfield, VA 22161

Telephone 703-605-6000 (1-800-553-6847)

TDD 703-487-4639

Fax 703-605-6900

E-mail info@ntis.gov

Web site http://www.ntis.gov/support/ordernowabout.htm

Reports are available to DOE employees, DOE contractors, Energy Technology Data Exchange (ETDE) representatives, and International Nuclear Information System (INIS) representatives from the following source.

Office of Scientific and Technical Information

P.O. Box 62

Oak Ridge, TN 37831

Telephone 865-576-8401

Fax 865-576-5728

E-mail reports@osti.gov

Web site http://www.osti.gov/contact.html

This report was prepared as an account of work sponsored by an agency of the United States Government. Neither the United States Government nor any agency thereof, nor any of their employees, makes any warranty, express or implied, or assumes any legal liability or responsibility for the accuracy, completeness, or usefulness of any information, apparatus, product, or process disclosed, or represents that its use would not infringe privately owned rights. Reference herein to any specific commercial product, process, or service by trade name, trademark, manufacturer, or otherwise, does not necessarily constitute or imply its endorsement, recommendation, or favoring by the United States Government or any agency thereof. The views and opinions of authors expressed herein do not necessarily state or reflect those of the United States Government or any agency thereof. 


\title{
Research Reactors Division
}

\section{ESTABLISHING SPECIFICATIONS FOR LOW ENRICHED URANIUM FUEL OPERATIONS} CONDUCTED OUTSIDE THE HIGH FLUX ISOTOPE REACTOR SITE

\author{
R. T. Primm, III \\ D. L. Pinkston \\ J. D. Sease \\ D. G. Renfro
}

September 2010

Prepared by

\section{OAK RIDGE NATIONAL LABORATORY}

P.O. Box 2008

Oak Ridge, Tennessee 37831-6285

managed by

UT-BATTELLE, LLC

For the

U.S. DEPARTMENT OF ENERGY

Under contract DE-AC05-00OR22725 


\section{CONTENTS}

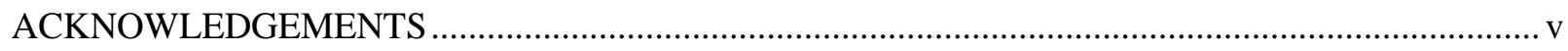

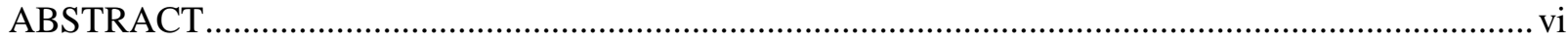

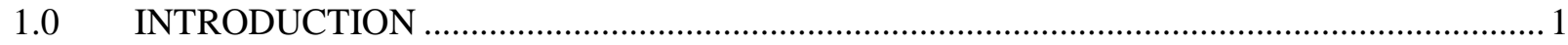

$2.0 \quad$ PROCESS FOR THE CREATION OF FUEL SPECIFICATIONS ......................................

3.0 ESTABLISHMENT OF INITIATION DATE FOR FUEL SPECIFICATION

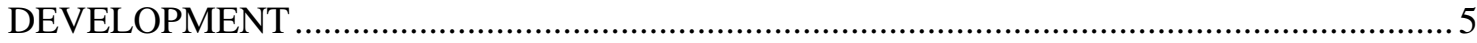

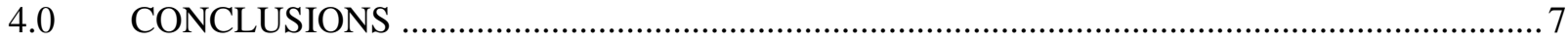

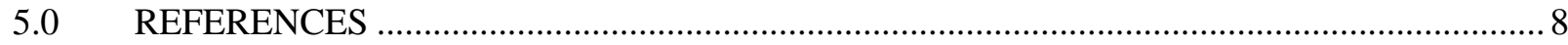
APPENDIXES

A. FUEL SPECIFICATION FOR THE PRODUCTION OF $\mathrm{U}_{3} \mathrm{O}_{8}$ POWDER............................. 9

B. SPECIFICATION FOR THE PRODUCTION OF HFIR HEU FUEL ELEMENTS................23

C. BOISE STATE TECENTER TECHNOLOGY COMMERCIALIZATION MODEL...............64 


\section{ACKNOWLEDGEMENTS}

This work was funded by the National Nuclear Security Administration and sponsored by Dr. Parrish Staples of NNSA. L. D. Proctor, Research Reactors Division (RRD), Oak Ridge National Laboratory (ORNL) provided assistance with identifying Department of Energy (DOE) regulations that are applicable to development of fuel specifications. Dr. Kevin Smith, RRD/ORNL performed a technical review of this work. 


\begin{abstract}
The National Nuclear Security Administration (NNSA) has funded staff at Oak Ridge National Laboratory (ORNL) to study the conversion of the High Flux Isotope Reactor (HFIR) from the current, high enriched uranium fuel to low enriched uranium fuel. The LEU fuel form is a metal alloy that has never been used in HFIR or any HFIR-like reactor. This report provides documentation of a process for the creation of a fuel specification that will meet all applicable regulations and guidelines to which UT-Battelle, LLC (UTB) - the operating contractor for ORNL - must adhere. This process will allow UTB to purchase LEU fuel for HFIR and be assured of the quality of the fuel being procured.
\end{abstract}




\subsection{INTRODUCTION}

The National Nuclear Security Administration (NNSA) has funded staff at Oak Ridge National Laboratory (ORNL) to study the conversion of the High Flux Isotope Reactor (HFIR) from the current, high enriched uranium (HEU) fuel to low enriched uranium (LEU) fuel. The LEU fuel form - a metal alloy composed of uranium and 10\% molybdenum by weight (U-10Mo) - and a tentative production scheme have been documented in Ref. 1 . The fuel will not be fabricated at ORNL (as the initial HEU fuel was) nor will the operating contractor for HFIR - UT-Battelle, LLC (UTB) - have any manufacturing role in the production of the LEU fuel. The UTB role will be limited to the purchase of the product.

The LEU fuel is a different physical form than the current HEU fuel; the HEU being a mixture of $\mathrm{U}_{3} \mathrm{O}_{8}$ and aluminum powders. The U-10Mo alloy has never been used in HFIR or any HFIR-like reactor. Furthermore, limited experience exists within the HFIR staff regarding the creation of fuel production processes since the HFIR HEU fuel specifications and production procedures are essentially unchanged since the HEU fuel fabrication process was created in the mid-1960s.

Reference 1 notes that the start of the LEU production process is the assignment of HEU to the production scheme. Thus the initial steps in LEU production will be in the secure area of the Y12 National Security Complex. Subsequent to blend-down of HEU to LEU, economic considerations will lead to the remaining LEU plate production steps being outside the secure area. Thus there are at least two geographic locations for the LEU process and likely, but not necessarily, at least two vendors. By coincidence (and history), this same separation occurs in the current HEU process and results in two fuel specifications for HEU fuel. These two specifications are reproduced in Appendices A and B and it is the development of U-10Mo counterparts to Appendix A and the plate production processes in Appendix B that are the subjects of this study. As noted in Ref. 1, after HFIR fuel plates have been fabricated, the remainder of the LEU fuel production process will be the same as for the current, HEU fuel. The authors' goal is the establishment of a process for the creation of a fuel specification that will meet all applicable regulations and guidelines to which UT-Battelle, LLC must adhere. ${ }^{*}$ This process will allow UTB to purchase LEU fuel for HFIR and be assured of the quality of the fuel being procured.

Operation of the Y-12 National Security Facility is the responsibility of the NNSA. LEU program management have informed HFIR staff that once a production process for LEU has been developed, the portions of the process following the blend-down of HEU would be in a facility that would be the responsibility of another entity in the Department of Energy (possibly Office of Nuclear Energy or Office of Science). The HFIR is a Department of Energy, Office of Science facility. Thus an established, LEU fuel cycle for HFIR will require cooperation among multiple entities within the Department of Energy.

\footnotetext{
* The authors recognize that the LEU fabrication process may have multiple vendors and multiple fuel specifications. For simplicity, references to vendors and specifications are made singular in tense.
} 


\subsection{PROCESS FOR THE CREATION OF FUEL SPECIFICATIONS}

Research and development of the LEU, U-10Mo fuel (monolithic form) is the responsibility of the Global Threat Reduction Initiative (GTRI) Reduced Enrichment for Research and Test Reactors (RERTR) program. Responsibility for the research and development operations has been assigned to the Idaho National Laboratory. An assumption made for this study is that the research and development being conducted by INL is being performed in accordance with nuclear quality assurance standard, NQA-1 Subpart 4.2.

Production of reactor fuel is a joint responsibility of the reactor owner and the fuel vendor. The reactor owner is responsible for: creating and maintaining the fuel specification, being informed as to the procedures of the fuel vendor that are created by the vendor in order to produce a product that meets the specification, accepting responsibility that the quality assurance procedures created by the fuel vendor are adequate to assure that the fuel produced meets the specification, and for auditing the vendor to insure that the procedures are followed.

The operating contract for ORNL (including HFIR) between UT-Battelle and the United States Department of Energy (DOE) specifies rules and regulations that are applicable to HFIR operations and HFIR fuel procurement. The contracting requirement most applicable to the study presented here is the stipulation that "Contractors conducting activities, including providing items or services, that affect, or may affect, the nuclear safety of DOE nuclear facilities must conduct work in accordance with the Quality Assurance criteria in (Code of Federal Regulations, CFR) Sec. 830.122.” In addition to 10 CFR 830, UTB is contractually obligated to DOE Order 414.1C (the quality assurance order). That Order requires that UTB adopt a consensus QA standard. UTB/HFIR staff have adopted NQA-1 2000 Part 1 through the Department of Energy process identified as "work smart standards." The work smart standards are incorporated into the UTB contract with the Department of Energy.

Adherence to fuel procurement regulations - those that are non-business related - is achieved via the quality assurance portions of the fuel specifications, i.e. the fuel specifications demonstrate adherence of UTB (HFIR) to NQA-1. The achievement of operation requirements is documented in the HFIR Safety Analysis Report (SAR). ${ }^{2}$ That report will have to be updated for LEU fuel based on analyses performed by HFIR staff and data obtained from the NNSA LEU fuel development program. ${ }^{3}$ In many instances, the sources of input to the analyses that are the basis for the HFIR SAR are the fuel specifications. Thus the new fuel specification to be developed for LEU fuel is one of the mechanisms for insuring the nuclear safety of HFIR as required by 10CFR830 and the mechanism for insuring adherence to DOE Order 414.1C.

The Research Reactors Division at ORNL maintains an "internal” document, RRD Systems Engineering procedure SEP-0225, the stated purpose of which is "to control the initial development, and subsequent revisions to System Design Descriptions (SDD), Component Design Specifications (CDS), Material Specifications (MS) Job Specifications (JS), and General Procurement Specifications (GPS)." Note that fuel specification is not specified though could be considered as being a "component specification" or a "material specification." Review of this procedure showed that it presents, in general terms, the expected content of a specification but not the procedure for creating a specification, especially when outside organizations must be involved in specification development, nor does it specify the time in the development process at which a specification should be developed. The procedure seems based on the implicit assumption that a product, component, or material is available. 
The creation of a fuel specification for HFIR U-10Mo should follow the process established by the International Organization for Standardization. ${ }^{4}$ While the authors acknowledge that ref. 4 is intended for use among countries for established products, the philosophy employed in this process is applicable to the development of an LEU fuel cycle. The ISO process is described by an extensive set of references available from the link that is ref. 4. A brief summary of the process is presented below but with text modified to be applicable to LEU fuel for HFIR.

International standards are developed by ISO technical committees (TC) and subcommittees (SC) by a six-step process:

- Stage 1: Proposal

- $\quad$ Stage 2: Preparatory

- Stage 3: Committee

- Stage 4: Enquiry

- Stage 5: Approval

- Stage 6: Publication

Stage 1: Proposal Stage (unneeded, LEU is a new process so there must be a new standard).

Stage 2: Preparatory Stage - A working group of experts from or contracted to ORNL, the chairman (convener) of which is the project leader, is set up for the preparation of a working draft. The working group will also include representatives from the vendors. Successive working drafts may be considered until the working group is satisfied that it has developed the best technical solution to the problem being addressed.

Stage 3: Committee Stage - At this stage, the draft is forwarded to ORNL and vendor management for the consensus-building phase. Once consensus has been attained, the text is finalized for submission as a draft Research Reactors Division (RRD) specification.

Stage 4: Enquiry Stage - The draft RRD standard (DIS) is circulated to all Department of Energy (DOE) bodies including NNSA, Office of Science, and whichever office or entity is responsible for the fuel plate fabrication facility. Comments should be made within a period of five months. It is approved for submission as a final RRD standard if approved by the DOE Office of Science. If the approval criteria are not met, the text is returned to the originating Stage 2 for further study and a revised document will again be circulated for approval and comment as a draft RRD standard.

Stage 5: Approval stage (linked with stage 4 for the LEU process).

Stage 6: Publication Sage - Once a final draft RRD standard has been approved, only minor editorial changes, if and where necessary, are introduced into the final text. The final text is sent to RRD Document Control which publishes the specification.

The ISO process includes a useful "stage code table" that allows for tracking of the standard development process. The table is reproduced as Fig. 1. Certainly, many of the steps are unnecessary for LEU process development but the implied rigor of standard development should be adopted for the LEU process. 


\section{International harmonized stage codes}

\begin{tabular}{|c|c|c|c|c|c|c|c|}
\hline \multirow[t]{3}{*}{ STAGE } & \multicolumn{7}{|l|}{ SUBSTAGE } \\
\hline & \multirow[b]{2}{*}{$\begin{array}{l}00 \\
\text { Registration }\end{array}$} & \multirow[b]{2}{*}{$\begin{array}{l}20 \\
\text { Start of main } \\
\text { action }\end{array}$} & \multirow[b]{2}{*}{$\begin{array}{l}60 \\
\text { Completion } \\
\text { of main } \\
\text { action }\end{array}$} & \multicolumn{4}{|c|}{$\begin{array}{l}90 \\
\text { Decision Substages }\end{array}$} \\
\hline & & & & $\begin{array}{l}92 \\
\text { Repeat an } \\
\text { earlier phase }\end{array}$ & $\begin{array}{l}93 \\
\text { Repeat } \\
\text { current phase }\end{array}$ & $\begin{array}{l}98 \\
\text { Abandon }\end{array}$ & $\begin{array}{l}99 \\
\text { Proceed }\end{array}$ \\
\hline $\begin{array}{l}00 \\
\text { Preliminary } \\
\text { stage }\end{array}$ & $\begin{array}{l}00.00 \\
\text { Proposal for } \\
\text { new project } \\
\text { received }\end{array}$ & $\begin{array}{c}00.20 \\
\text { Proposal for } \\
\text { new project } \\
\text { under review }\end{array}$ & $\begin{array}{l}00.60 \\
\text { Close of } \\
\text { review }\end{array}$ & & & $\begin{array}{c}00.98 \\
\text { Proposal for } \\
\text { new project } \\
\text { abandoned }\end{array}$ & $\begin{array}{c}00.99 \\
\text { Approval to } \\
\text { ballot proposal } \\
\text { for new project }\end{array}$ \\
\hline $\begin{array}{l}10 \\
\text { Proposal } \\
\text { stage }\end{array}$ & $\begin{array}{c}10.00 \\
\text { Proposal for } \\
\text { new project } \\
\text { registered }\end{array}$ & $\begin{array}{c}10.20 \\
\text { New project } \\
\text { ballot initiated }\end{array}$ & $\begin{array}{l}10.60 \\
\text { Close of } \\
\text { voting }\end{array}$ & $\begin{array}{l}10.92 \\
\text { Proposal } \\
\text { returned to } \\
\text { submitter for } \\
\text { further } \\
\text { definition }\end{array}$ & & $\begin{array}{c}10.98 \\
\text { New project } \\
\text { rejected }\end{array}$ & $\begin{array}{c}10.99 \\
\text { New project } \\
\text { approved }\end{array}$ \\
\hline $\begin{array}{l}20 \\
\text { Preparatory } \\
\text { stage }\end{array}$ & $\begin{array}{l}20.00 \\
\text { New project } \\
\text { registered in } \\
\text { TC/SC work } \\
\text { programme }\end{array}$ & $\begin{array}{c}20.20 \\
\text { Working draft } \\
\text { (WD) study } \\
\text { initiated }\end{array}$ & $\begin{array}{l}20.60 \\
\text { Close of } \\
\text { comment } \\
\text { period }\end{array}$ & & & $\begin{array}{l}20.98 \\
\text { Project } \\
\text { deleted }\end{array}$ & $\begin{array}{c}20.99 \\
\text { WD approved } \\
\text { for registration } \\
\text { as CD }\end{array}$ \\
\hline $\begin{array}{l}30 \\
\text { Committee } \\
\text { stage }\end{array}$ & $\begin{array}{l}30.00 \\
\text { Committee } \\
\text { draft }(C D) \\
\text { registered }\end{array}$ & $\begin{array}{c}30.20 \\
\mathrm{CD} \\
\text { study/ballot } \\
\text { initiated }\end{array}$ & $\begin{array}{l}30.60 \\
\text { Close of } \\
\text { votingl } \\
\text { comment } \\
\text { period }\end{array}$ & $\begin{array}{c}30.92 \\
\text { CD referred } \\
\text { back to } \\
\text { Working } \\
\text { Group }\end{array}$ & & $\begin{array}{l}30.98 \\
\text { Project } \\
\text { deleted }\end{array}$ & $\begin{array}{c}30.99 \\
\text { CD approved } \\
\text { for registration } \\
\text { as DIS }\end{array}$ \\
\hline $\begin{array}{l}40 \\
\text { Enquiry } \\
\text { stage }\end{array}$ & $\begin{array}{c}40.00 \\
\text { DIS registered }\end{array}$ & $\begin{array}{c}40.20 \\
\text { DIS ballot } \\
\text { initiated: } 5 \\
\text { months }\end{array}$ & $\begin{array}{l}40.60 \\
\text { Close of } \\
\text { voting }\end{array}$ & $\begin{array}{c}40.92 \\
\text { Full report } \\
\text { circulated: } \\
\text { DIS referred } \\
\text { back to TC or } \\
\text { SC }\end{array}$ & $\begin{array}{c}40.93 \\
\text { Full report } \\
\text { circulated: } \\
\text { decision for } \\
\text { new DIS } \\
\text { ballot }\end{array}$ & $\begin{array}{l}40.98 \\
\text { Project } \\
\text { deleted }\end{array}$ & $\begin{array}{c}40.99 \\
\text { Full report } \\
\text { circulated: DIS } \\
\text { approved for } \\
\text { registration as } \\
\text { FDIS }\end{array}$ \\
\hline $\begin{array}{l}50 \\
\text { Approval } \\
\text { stage }\end{array}$ & $\begin{array}{c}50.00 \\
\text { FDIS } \\
\text { registered for } \\
\text { formal } \\
\text { approval }\end{array}$ & $\begin{array}{l}50.20 \\
\text { FDIS ballot } \\
\text { initiated: } 2 \\
\text { months. } \\
\text { Proof sent to } \\
\text { secretariat }\end{array}$ & $\begin{array}{l}50.60 \\
\text { Close of } \\
\text { voting. } \\
\text { Proof } \\
\text { returned by } \\
\text { secretariat }\end{array}$ & $\begin{array}{c}50.92 \\
\text { FDIS referred } \\
\text { back to TC or } \\
\text { SC }\end{array}$ & & $\begin{array}{l}50.98 \\
\text { Project } \\
\text { deleted }\end{array}$ & $\begin{array}{l}50.99 \\
\text { FDIS } \\
\text { approved for } \\
\text { publication }\end{array}$ \\
\hline $\begin{array}{l}60 \\
\text { Publication } \\
\text { stage }\end{array}$ & $\begin{array}{c}60.00 \\
\text { International } \\
\text { Standard } \\
\text { under } \\
\text { publication }\end{array}$ & & $\begin{array}{c}60.60 \\
\text { International } \\
\text { Standard } \\
\text { published }\end{array}$ & & & & \\
\hline $\begin{array}{l}90 \\
\text { Review } \\
\text { stage }\end{array}$ & & $\begin{array}{c}90.20 \\
\text { International } \\
\text { Standard } \\
\text { under } \\
\text { periodical } \\
\text { review }\end{array}$ & $\begin{array}{l}90.60 \\
\text { Close of } \\
\text { review }\end{array}$ & $\begin{array}{l}90.92 \\
\text { International } \\
\text { Standard to } \\
\text { be revised }\end{array}$ & $\begin{array}{c}90.93 \\
\text { International } \\
\text { Standard } \\
\text { confirmed }\end{array}$ & & $\begin{array}{c}90.99 \\
\text { Withdrawal of } \\
\text { International } \\
\text { Standard } \\
\text { proposed by } \\
\text { TC or SC }\end{array}$ \\
\hline $\begin{array}{l}95 \\
\text { Withdrawal } \\
\text { stage }\end{array}$ & & $\begin{array}{c}95.20 \\
\text { Withdrawal } \\
\text { ballot initiated }\end{array}$ & $\begin{array}{l}95.60 \\
\text { Close of } \\
\text { voting }\end{array}$ & $\begin{array}{l}95.92 \\
\text { Decision not } \\
\text { to withdraw } \\
\text { International } \\
\text { Standard }\end{array}$ & & & $\begin{array}{c}95.99 \\
\text { Withdrawal of } \\
\text { International } \\
\text { Standard }\end{array}$ \\
\hline
\end{tabular}

Fig. 1. ISO stage codes used to track standard development (ref. 4). 


\subsection{ESTABLISHMENT OF INITIATION DATE FOR FUEL SPECIFICATION DEVELOPMENT}

Obviously the process described in Section 2.0 would have to be completed prior to the production of the first HFIR LEU core. However the process cannot be initiated until an adequate amount of fuel research and development has been completed. That R\&D is needed to enable the industrial process to be defined to the level of precision that will yield quantitative input on manufacturing tolerances and measurement uncertainties. A useful categorization of industrialization stages is presented Appendix C (ref. 5) though many other references provide similar discussion. Clearly many steps on the tables in Appendix $C$ are not applicable to the LEU fuel development program but the stage definitions are useful.

Based on the "Key Questions” table in Appendix C for HFIR LEU fuel, the RERTR program is currently at Stage 2, Step 6, since a prototype of a HFIR LEU fuel plate has not yet been fabricated. Based on the "Activities Table" in Appendix C, the standards development process described in Section 2.0 should begin in Stage 4, Step 10.

Figure 2 is the LEU conversion schedule for high performance, United States reactors that was presented at NNSA and distributed in March 2010. While the designations in Fig. 2 do not map well to Appendix C, the date of January 2012 for commercial contract awarded would seem to match to Stage 4, Step 10 of Appendix C and thus should be the nominal starting time for fuel specification development.

A prototype, HFIR, U-10Mo fuel plate has not yet been constructed. Consequently it is not yet time to begin the fuel specification process. The process is expected to be initiated at the time that a commercial fabricator is selected. However, because initial LEU fabrication steps will involve HEU, that contractor (BWXT-Y12) is known and specifications for the "head end" of the process could be initiated prior to the selection of the commercial fabricator. Final approval of the "head end" fuel specification should await selection of and review by the commercial fabricator. 


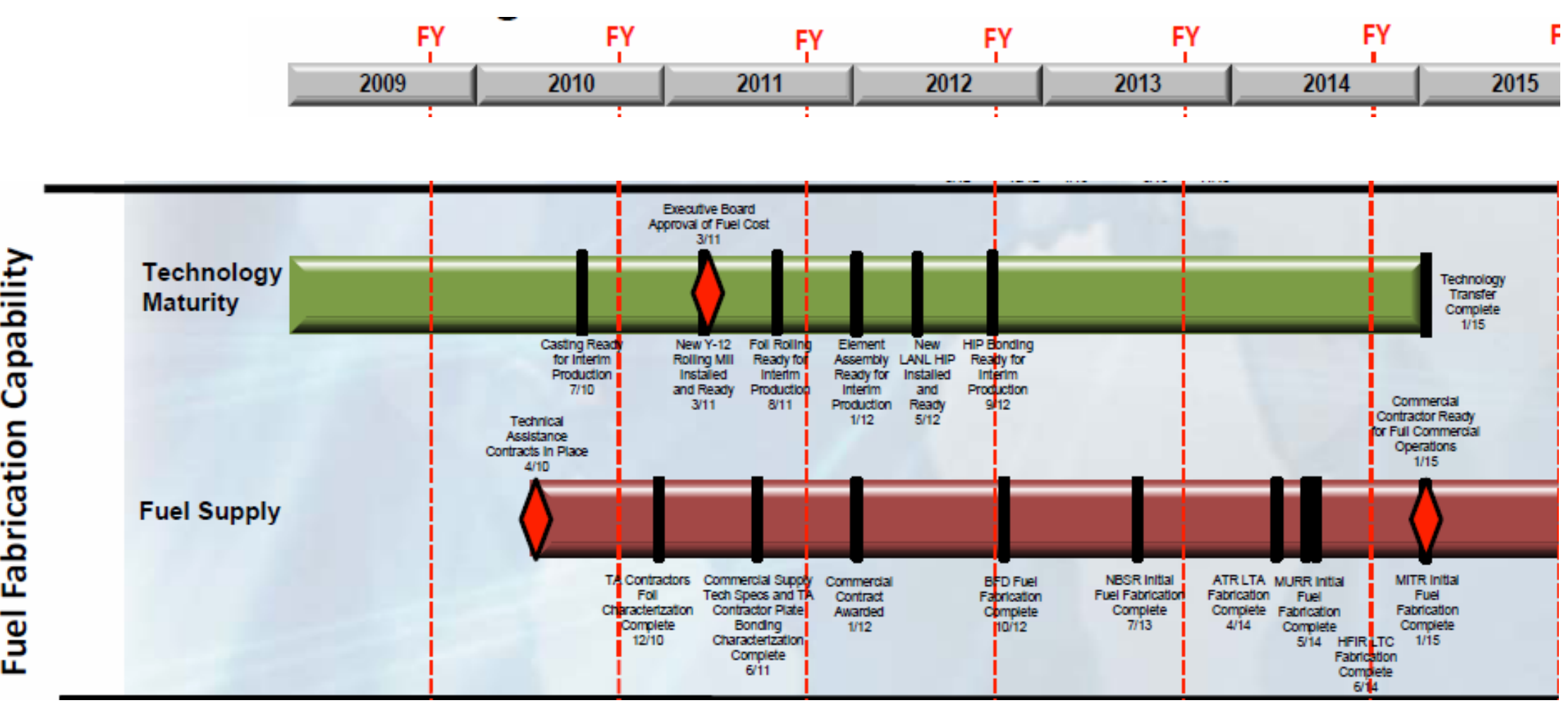

Fig. 2. Portion of NNSA, U.S. high performance reactor conversions schedule, March 2010. 


\subsection{CONCLUSIONS}

Development of an LEU-10Mo fuel specification that corresponds to existing HEU fuel specifications is the mechanism for implementing quality assurance regulations to which the contractor for ORNL is obligated. Because the research and development (R\&D) of the U-10Mo fuel is not the responsibility of UT-Battelle/ORNL, the assumption is made that all such work is in conformance with Nuclear Quality Assurance Standard 1 (NQA-1), Subpart 4.2. It is the responsibility of the LEU R\&D contractor(s) to provide documentation to UT-Battelle of the validity of the assumption.

A prototype, HFIR, U-10Mo fuel plate has not yet been constructed. Consequently it is not yet time to begin the fuel specification process for fuel plates. However, a separate specification document could be prepared for the initial stages of the fuel production process. The contractor for the HEU stages will be BWXT-Y12 and a specification for the production step through the creation of U-10Mo foils could be initiated prior to the selection of the commercial fabricator for fuel plate and element production.

Creation of a fuel specification can be achieved by following a process similar to that endorsed by the international standards organization. A committee composed of staff from the reactor operator and the fuel vendors should be formed to create the specification. The specification will be the property of and maintained by the reactor operator. 


\subsection{REFERENCES}

1. J. D. Sease, R. T. Primm III, and J. H. Miller, Conceptual Process for the Manufacture of Lowenriched Uranium/Molybdenum Fuel for the High Flux Isotope Reactor, ORNL/TM-2007/39, September 2007.

2. ORNL/HFIR/USAR/2344, HFIR Updated Safety Analysis Report, Revision 6.

3. D. M Wachs, RERTR Fuel Development and Qualification Plan, INL/EXT-05-01017, Rev. 4, August 2009.

4. http://www.iso.org/iso/standards development/processes and_procedures/stages description.htm l, September 29, 2010.

5. http://www.bsutecenter.com/Tools__Links/ September 29, 2010. 
APPENDIX A

FUEL SPECIFICATION FOR THE PRODUCTION OF $\mathrm{U}_{3} \mathrm{O}_{8}$ POWDER 
ORNL RESEARCH REACTORS DIVISION

ENGINEERING STANDARDS AND SPECIFICATIONS

ORNL/RRD/INT-37, VOLUME 4

\author{
RRD-MS-106, REV. 1 \\ SPECIFICATION FOR \\ $\mathrm{U}_{3} \mathrm{O}_{8}$ POWDER FOR MANUFACTURING HFIR FUEL PLATES
}

Prepared by:

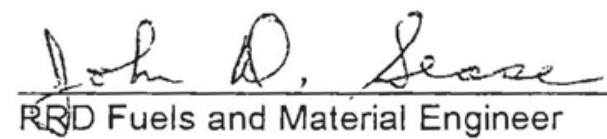

Reviewed by:
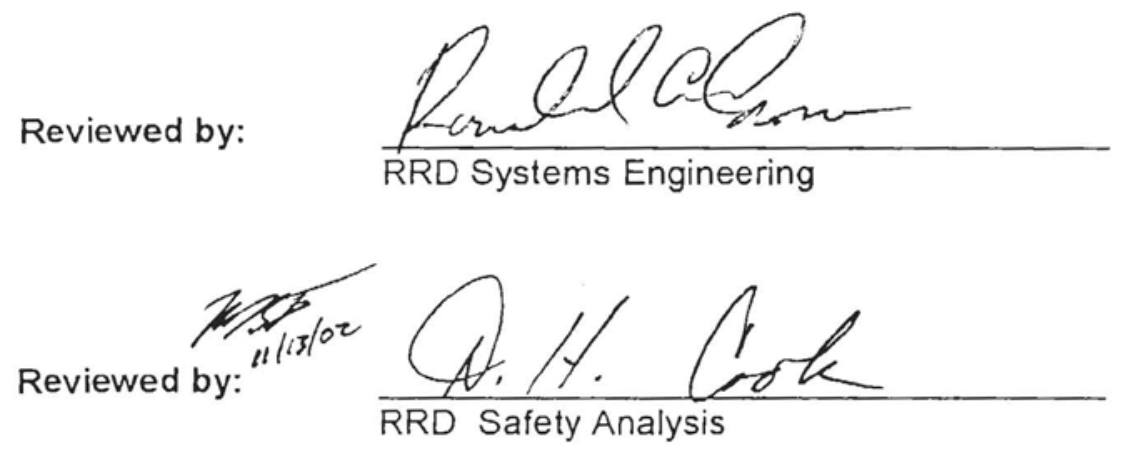

Reviewed by:

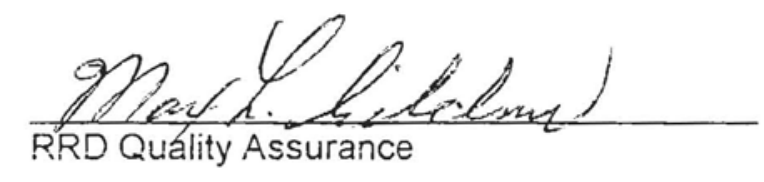

Approved by:

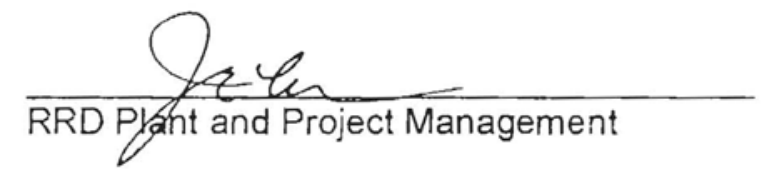

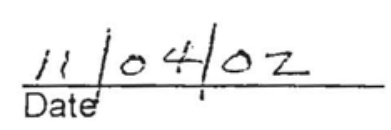

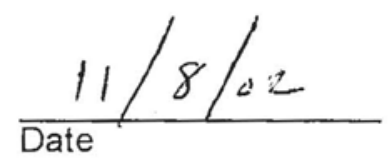

$\frac{11-12-02}{\text { Date }}$

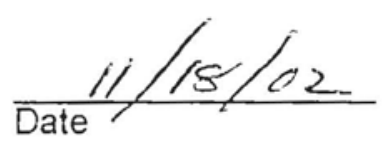

$\frac{11 / 18 / 82}{\text { Date }}$ 
ORNL RESEARCH REACTORS DIVISION ENGINEERING STANDARDS AND SPECIFICATIONS

\section{SPECIFICATION FOR $\mathrm{U}_{3} \mathrm{O}_{8}$ POWDER \\ FOR MANUFACTURING HFIR FUEL PLATES}

\section{TABLE OF CONTENTS}

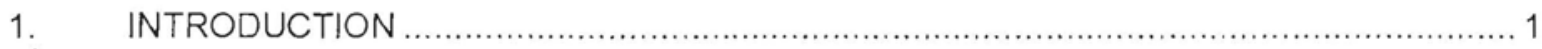

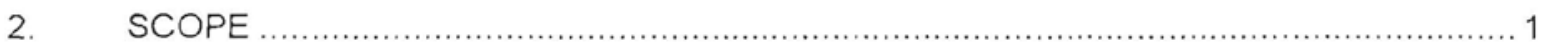

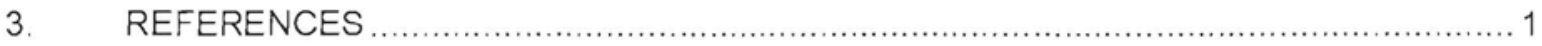

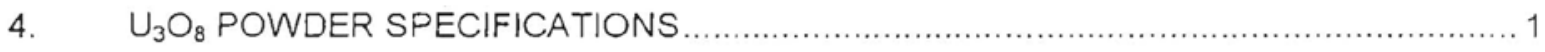

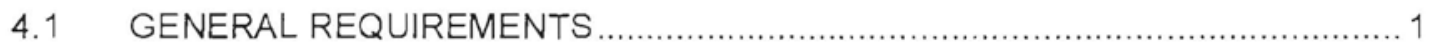

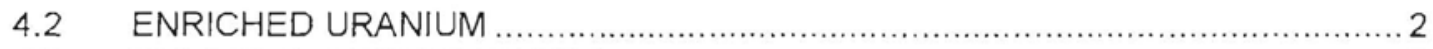

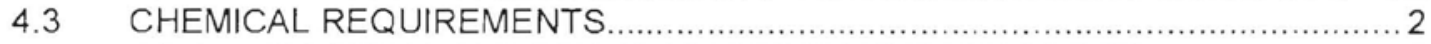

4.3.1 CHEMICAL AND TRACE ELEMENTS REQUIREMENTS …................... 2

4.3.2 HEALTH PHYSICS REQUIREMENTS ............................................. 3

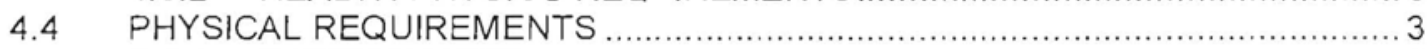

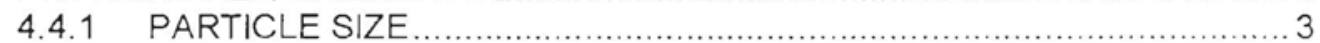

4.4 .2 SURFACE AREA …......................................................................... 3

$4.4 .3 \quad$ PARTICIE DENSITY .............................................................. 3

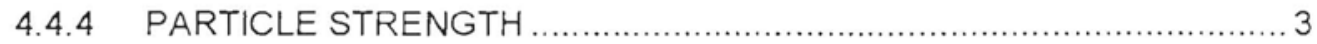

4.4.5 PARTICLE SHAPE AND MICROSTRUCTURE ................................. 3

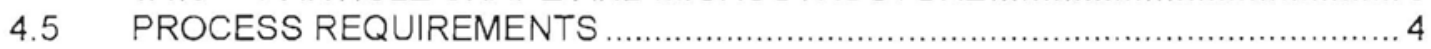

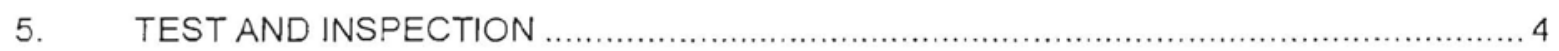

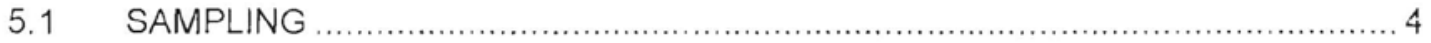

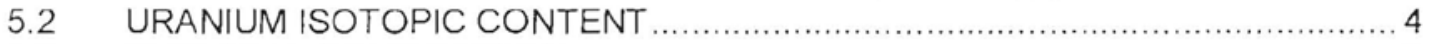

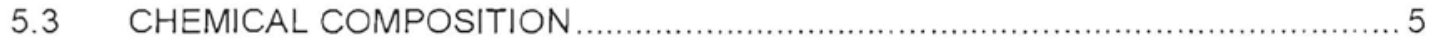

5.3.1 CHEMICAL AND TRANCE ELEMENT REQUIREMENTS .................... 5

5.3.2 HEALTH PHYSICS REQUIREMENTS ........................................ 5

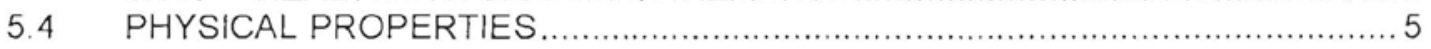

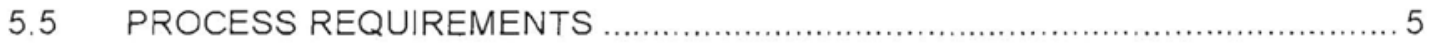

6. SHIPPING REQUIREMENTS …

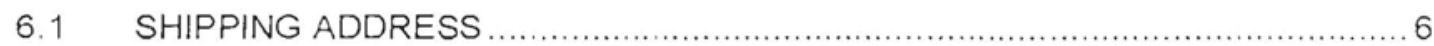

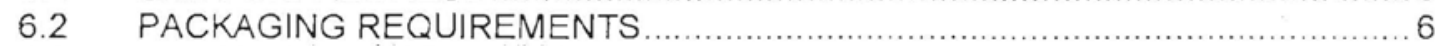

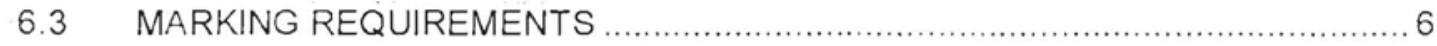

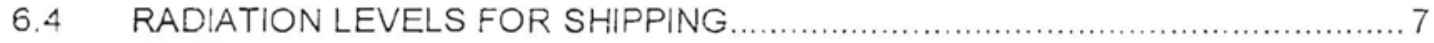

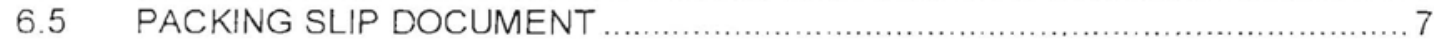

Page $i$ of ii 
ORNL RESEARCH REACTORS DIVISION ENGINEERING STANDARDS AND SPECIFICATIONS ORNL/RRD/INT-37/V4 RRD-MS-106, R1

\section{SPECIFICATION FOR $\mathrm{U}_{3} \mathrm{O}_{8}$ POWDER FOR MANUFACTURING HFIR FUEL PLATES}

TABLE OF CONTENTS (CONT)

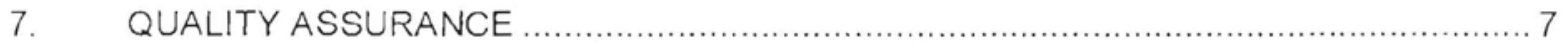

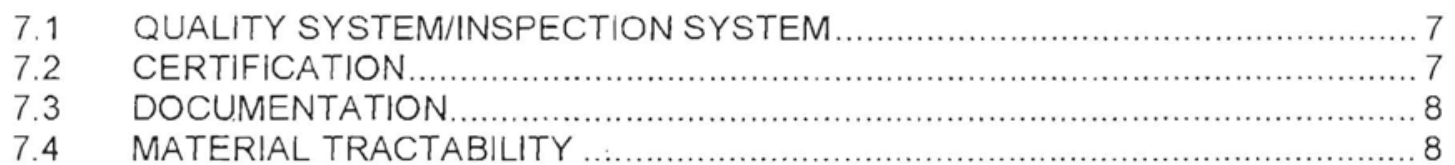

Page ii of ii 


\section{ORNL RESEARCH REACTORS DIVISION \\ ENGINEERING STANDARDS AND SPECIFICATIONS \\ ORNLIRRD/INT-37/V4 \\ RRD-MS-106, R1}

\section{SPECIFICATION FOR $U_{3} \mathrm{O}_{8}$ POWDER FOR MANUFACTURING HFIR FUEL PLATES}

\section{INTRODUCTION}

The revision to the specification is to provide more definitive requirements learned since the Rev. 0 was issued in 1998.

\section{SCOPE}

This specification will define the $U_{3} \mathrm{O}_{8}$ powder containing $93 \%$ enriched uranium to be procured for use in the manufacture of fuel plates for the High Flux Isotope Reactor (HFIR). The $\mathrm{U}_{3} \mathrm{O}_{8}$ powder will be blended with aluminum powder to form the fuel sections in the fuel compacts used to make fuel plates for both inner and outer HFIR fuel elements. The $\mathrm{U}_{3} \mathrm{O}_{8}$ qualified under this specification will be used in the manufacture of $\mathrm{U}_{3} \mathrm{O}_{8}$ fuel elements for the NIST Reactor and may also be used in the manufacture of fuel elements for other research reactors.

\section{REFERENCES}

1. American Society For Testing and Materiais (ASTM), Standard Test Method for Sieve Analysis of Granular Metal Powder, ASTM B 214-(latest revision).

2. ASTM:C 1462-00 "Standard Specification for Uranium Mietal Enricheul to More Than $15 \%$ and less than $20 \% 235 \mathrm{U}^{\prime \prime}$.

3. ASTM C 1233097 " Standard Practice for Determining Equivalent Boron Contents of Nuclear Materials".

4. W. J. Werner and J. R. Barkman, ORNL-4052, Characterization and Production of $\mathrm{U}_{3} \mathrm{O}_{8}$ for the High Flux Isotope Reactor, Oak Ridge National Lab., April 1967.

\section{4. $\mathrm{U}_{3} \mathrm{O}_{6}$ POWDER SPECIFICATIONS}

\subsection{GENERAL REQUIREMENTS}

The $\mathrm{U}_{3} \mathrm{O}_{8}$ powder shall contain $93 \%$ enriched uranium and shall be dense particles (>94\% of theoretical density) of $\mathrm{U}_{3} \mathrm{O}_{8}$ with a nominal particle size of - $170+325$ US Standard mesh size. The powder particles shall be made by a precipitation and high temperature (i.e., $1400 \mathrm{C}$ ) air atmosphere sintering process. Particles produced in any other manner shall be determined to be equivalent based on homogeneity data from pre-production plate lots.

\section{Page 1 of 8}




\section{ORNL RESEARCH REACTORS DIVISION ENGINEERING STANDARDS AND SPECIFICATIONS \\ ORNL/RRD/INT-37/V4 RRD-MS-106, R1}

\section{SPECIFICATION FOR $U_{3} \mathrm{O}_{8}$ POWDER FOR MANUFACTURING HFIR FUEL PLATES}

\subsection{ENRICHED URANIUM}

The enriched uranium contained in the $U_{3} \mathrm{O}_{8}$ shall contain nominally $>93 \%{ }^{235} U$ in total $U$ with an allowable ${ }^{235} U$ isotopic concentration of $92-94 \%$ in total $U$. The isotopic content of the uranium shall be measured to within $+/-0.1 \%$.

\subsection{CHEMICAL REQUIREMENTS}

The powder shall be dry and free from volatiles, oil and grease.

\subsubsection{CHEMICAL AND TRACE ELEMENTS REQUIREMENTS}

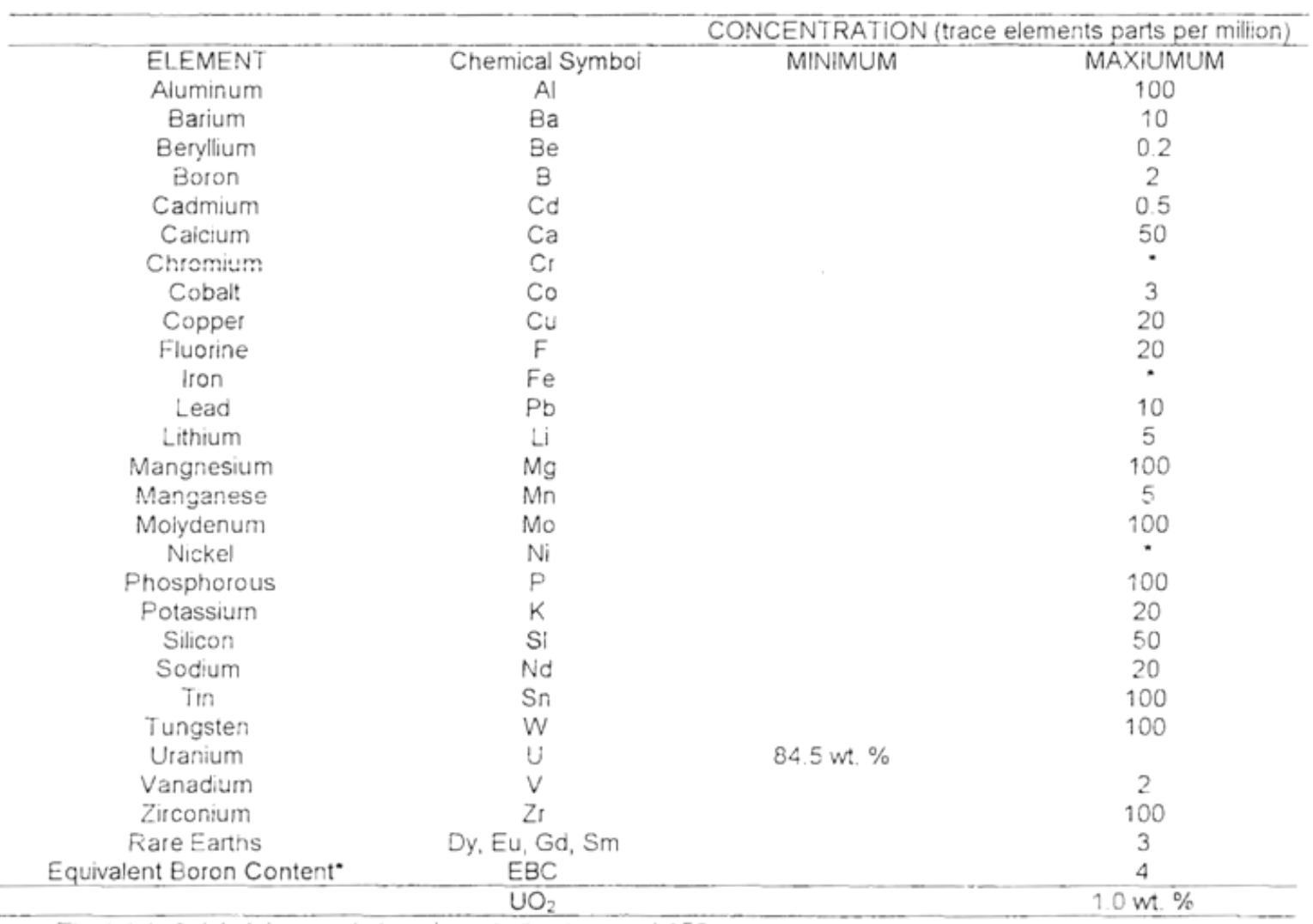

- The total of nickel, iron and chromium shall not exceed $150 \mathrm{ppm}$

-NOTE: ESC factor from ASTM C 1233-97, "Standard Practice for Determining Equivalent Eoron Content of Nuclear Materials". 


\section{ORNL RESEARCH REACTORS DIVISION ENGINEERING STANDARDS AND SPECIFICATIONS \\ ORNL/RRD/INT-37/V4 \\ RRD-MS-106, R1}

\section{SPECIFICATION FOR $\mathrm{U}_{3} \mathrm{O}_{8}$ POWDER \\ FOR MANUFACTURING HFIR FUEL PLATES}

\subsubsection{HEALTH PHYSICS REQUIREMENTS}

The gamma activity shall be $<600 \mathrm{~Bq} / \mathrm{gU}$. The total alpha activity from transuranium elements shall be $<250 \mathrm{~Bq} / \mathrm{gU}$.

\subsection{PHYSICAL REQUIREMENTS}

\subsubsection{PARTICLE SIZE}

The $\mathrm{U}_{3} \mathrm{O}_{8}$ powder shall consist of dense granular powder particles free from all foreign material. One hundred percent of the production sieved powder shall pass through a 170 mesh U.S. Standard screen and be retained on a 325 mesh U.S. Standard screen. The nominal particle size distribution (PSA) as determined by ASTM B.214 (latest revision) shall be as follows:

$\begin{array}{ll}+170 & <1 \% \\ -170+325 & >90 \% \\ -325 & <10 \%\end{array}$

\subsubsection{SURFACE AREA}

The surface area from the production sieved $-170+325$ product for a powder lot shall be $<.05$ $\mathrm{m}^{2} / \mathrm{g} \ldots$ as determined by the static krypton BET (see section 4.4.1). If -325 fines particles are added to a lot, the result surface area of the composite shall be $<.05 \mathrm{~m}^{2} / \mathrm{g}$.

\subsubsection{PARTICLE DENSITY}

The density of the $-170+325$ particles as determined by immersion density in toluene shall be $>8.2$ $\mathrm{g} / \mathrm{cc}$.

\subsubsection{PARTICLE STRENGTH}

The resistance of the production sieved $-170+325$ particles to degradation during subsequent fuel plate fabrication shall be determined by a particle size analysis per ASTM B 214. The maximum amount of -325 determined in the test shall be in compliance with Section 4.4.1.

\subsubsection{PARTICLE SHAPE AND MICROSTRUCTURE}

The particie shape from each batch shall be examined under a light microscope at 100X. The particle shape and aspect ratio shall be comparable with those shown in Y-12 photomicrograph Y73834 (see Aliachment 1. Page 1)(See W. J. Wermer and j. R. Barkam, ORNL-4052, Characterization and Production of $\mathrm{U}_{3} \mathrm{O}_{8}$ for the High Flux Isotope Reactor, Oak Ridge National Laboratory, Aprii 1967, page 13).

Page 3 of 8 


\title{
ORNL RESEARCH REACTORS DIVISION ENGINEERING STANDARDS AND SPECIFICATIONS \\ ORNL/RRD/INT-37/V4 \\ RRD-MS-106, R1
}

\author{
SPECIFICATION FOR $\mathrm{U}_{3} \mathrm{O}_{8}$ POWDER \\ FOR MANUFACTURING HFIR FUEL PLATES
}

A random sample of sintered $\cup_{3} \mathrm{O}_{8}$ particles from the first production batch in each lot shall be mounted and polished for microscopic examination. The sample shall be viewed at 200X and compared to Y-12 photomicrograph Y-73944 (see Attachment 2, Page 1) (See W. J. Werner and J. R. Barkman, ORNL-4052, Characterization and Production of $\mathrm{U}_{3} \mathrm{O}_{8}$ for the High Flux Isotope Reactor, Oak Ridge National Lab., April 1967, page 15). Any observable difference from the cited photomicrograph shall be called to the attention of the Buyer.

\subsection{PROCESS REQUIREMENTS}

The $\mathrm{U}_{3} \mathrm{O}_{8}$ powder particles sha!l be precipitated from a $\sim 20 \mathrm{~g}$ U/liter uranyl nitrate solution using hydrogen peroxide and ammonium hydroxide to control the $\mathrm{pH}$ at $2.0+l-.1$ to precipitate the uranium from solution. The $\mathrm{U}_{3} \mathrm{O}_{8}$ particles shall be formed by calcining the precipitated product at $850^{\circ} \mathrm{C}$ in nitrogen and subsequently sintered in air to a temperature $>1350^{\circ} \mathrm{C}$. If milling and sizing after sintering results in producing $>25 \%-325$ mesh particles, the remaining $-170+325$ product shall be resintered to $>1350 \mathrm{C}$. The buyer must approve the use of any other process.

A powder lot must represent one continuous production run of powder by the Supplier unless approved by the Buyer. The blending and dispensing of the batches used to constitute a powder lot shall be appropriate to minimize variations in the dispensed aliquots from each batch. The variations between individual containers used to constitute the lot shall be shown to be statistically insignificant.

\section{TEST AND INSPECTION}

\subsection{SAMPLING}

The sampling of the bulk product shall be by appropriate means to insure a representative sample for analysis.

\subsection{URANIUM ISOTOPEIC CONTENT}

The uranium isotopic analysis of enriched uranium feed materials that will be used to constitute a powder lot shall be determined by appropriate methods. The uranium isotopic content of each $\mathrm{U}_{3} \mathrm{O}_{8}$ powder lot shall be determined by the Supplier for conformance with Section 4.3.1 of this specification and reported to the Buyer.

Page 4 of 8 
ORNL/TM-2010/241

\author{
ORNL RESEARCH REACTORS DIVISION \\ ENGINEERING STANDARDS AND SPECIFICATIONS \\ ORNL/RRD/INT-37/V4 \\ RRD-MS-106, R1
}

\author{
SPECIFICATION FOR $U_{3} \mathrm{O}_{8}$ POWDER \\ FOR MANUFACTURING HFIR FUEL PLATES
}

\title{
5.3 CHEMICAL COMPOSITION
}

\subsubsection{CHEMICAL AND TRACE ELEMENTS REQUIREMENTS}

The chemical composition of the uranium, other chemicals and materials used in the process shall be analyzed by the Supplier at a sufficient sampling level to insure with a high probability that the trace element requirements listed in Section 4.3.1. can be achieved in the finished $\cup_{3} \mathrm{O}_{8}$ powder. The chemical composition requirements specified in Section 4.3.1 shall be performed on each powder batch produced for a powder lot. The Supplier shall report the actual values determined or the sensitivity of the test if the value is reporied as less than $(<)$ the required maximum vaiue. For the analytical values reported, an estimate of the accuracy and precision of the values reported shall be provided.

\subsubsection{HEALTH PHYSICS REQUIREIMENTS}

The gamma activity and total alpha activity from transuranium elements shall be reported for compliance with Section 4.3.2.

\subsection{PHYSICAL PROPERTIES}

A particle size distribution per ASTM B 214 (latest revision) shall be determined for the following particle sizes: $+170 ;-170+200 ;-200+230 ;-230+270 ;-270+325 ;-325$ U.S. Standard Mesh for each powder lot. The particle size distribution, surface area, and immersion density shall be determined on each $\mathrm{U}_{3} \mathrm{O}_{8}$ power lot for compliance with Section 4.4. A 100X light microscope photomicrographs of powder samples for batches composing a lot shall be made as specified in Section 4.4 .5 and a report prepared

The HFIR fuel fabricator shall make a $200 \mathrm{X}$ photomicrograph of a povider sample from each lot as specified in Section 4.4 .5 for comparative historical purposes.

\subsection{PROCESS REQUIREMENTS}

An outline flow sheet that will be used to produce the $\cup_{3} \mathrm{O}_{8}$ powder shall be provided to the Buyer prior to beginning of production operations.

A $1000 \mathrm{~g}$ sample of a candidate powder lot shall be submitted for evaluation and testing by the buyer prior to acceptance of the powder lot.

Before final acceptance of a $U_{3} \mathrm{O}_{3}$ powder lot, at least one lot (24 fuel plates) of HFIR fuel plates

Page 5 of 8 


\title{
ORNL RESEARCH REACTORS DIVISION \\ ENGINEERING STANDARDS AND SPECIFICATIONS \\ ORNL/RRD/INT-37/V4 \\ RRD-MS-106, R1
}

\author{
SPECIFICATION FOR $U_{3} \mathrm{O}_{8}$ POWDER \\ FOR MANUFACTURING HFIR FUEL PLATES
}

( $\sim 500 \mathrm{~g} \mathrm{U}_{3} \mathrm{O}_{5}$ ) shall be fabricated into flat roll bonded HFIR fuel plates and tested for compliance with the HFIR fuel dispersion homogeneity requirements. No more than 2 "spot defects" $(+27 \%)$ shall be allowed in the pre-production plate lot.

\section{SHIPPING REQUIREMENTS}

\subsection{SHIPPING ADDRESS}

The shipping address for $\mathrm{U}_{3} \mathrm{O}_{8}$ shall be as follows:

BWX Technologies, Inc.

Naval Nuclear Fuel Division

Mt. Athos Road

Lynchburg, VA 24505-0785

\subsection{PACKAGING REQUIREMENTS}

The $\mathrm{U}_{3} \mathrm{O}_{8}$ powder shall be contained in $\sim 2$ liter polyethylene bottles with $<7 \mathrm{~kg}$ 's of $U_{3} \mathrm{O}_{8}$ powder per bottle. Each plastic bottle shall be separately packaged in mild steel cans $\sim 41 / 4 \mathrm{in}$. diameter by 10 in. high with crimp iids sealed. The ioaded cans shail be loaded into Department of Transportation (DOT) approved nuclear material transportation packages for transport to BWXT in Lynchburg, VA. The number of cans contained in each shipping package shall be as appropriate in compliance with the DOT requirements for shipping the packages. The type of shipping package to be used and the requirements for the transfer of inventory and other information in advance of a shipment shall be by mutual agreement of the Shipper and Receiver.

\subsection{MARKING REQUIREMENTS}

Each p!astic bottle and can sha!l be cleariy marked with the following. All weights shall be recorded in grams.
(a) Lot identification
(b) Container identification
(c) Gross, Tare and Net Weight
(d) Weight of Plastic
(e) Weight of Paper
(f) Percentage ( Wt \%) of ${ }^{235} \mathrm{U}$ (enrichment) in total uranium
(g) Net Weight of $U$
(h) Net weight of ${ }^{235} \mathrm{U}$
(i) Percentage of total Uranium in $\mathrm{U}_{3} \mathrm{O}_{8}$ powder

Page 6 of 8 


\section{ORNL RESEARCH REACTORS DIVISION \\ ENGINEERING STANDARDS AND SPECIFICATIONS \\ ORNL/RRD/INT-37/V4 \\ RRD-MS-106, R1}

\section{SPECIFICATION FOR $\mathrm{U}_{3} \mathrm{O}_{8}$ POWDER FOR MANUFACTURING HFIR FUEL PLATES}

\subsection{RADIATION LEVELS FOR SHIPPING}

The contamination levels on the shipping container and inner containers (can and botile) shail be $<111 \mathrm{dpm} / 100 \mathrm{~cm}^{2}$ alpha and $<1000 \mathrm{dpm} / 100 \mathrm{~cm}^{2}$ beta.

\subsection{PACKING SLIP DOCUMENT}

A packing slip shall be attached to one of the shipping packages in the shipment and shall contain the following information:

(a) Name of individual responsible for Nuclear Material Receiving at BWXT

(b) Name of individual responsible for Nuclear Material Control at BWXT

(c) Radiological survey sheet with:

- indication of transport index

- individual survey of each can with the results in $\mathrm{mr} / \mathrm{hr}$.

- survey for loose surface contamination

- Hydrogen to $X$ ratios

(d) Tabulation by can and bottle contained in each shipping package for information listed in 6.3

(e) One copy of the certificate documentation for the material shipped.

\section{QUALITY ASSURANCE}

\subsection{QUIAL!TY SYSTEMIINSPECT!ON SYSTEM}

The supplier shall document, implement, and maintain a quality system which complies with the a na:ionaliy recognized standard, such as, NQÂ-1, ISO-9000, 10CFR50, Appendix B, or 10CFR830 Subpart A.

\subsection{CERTIFICATION}

The supplier shall compile and maintain one (1) data package, which shail include copies of test reports and all other data pertaining to the manufacture and inspection as specified in Sections 4 and 5 of this document. Specific identity by serial number of the product process shall be noted on all charts and certifications. Three copies of the certification documents signed by an authorized official of the Supplier will be supplied to the Buyer before or upon delivery of the product

The Supplier shall supply data to certify all requirements specified in Sections 4 and 5 have been acnieved to include:

$$
\text { Page } 7 \text { of } 8
$$


ORNL RESEARCH REACTORS DIVISION

ENGINEERING STANDARDS AND SPECIFICATIONS

ORNL/RRD/INT-37/V4

RRD-MS-106, R1

\section{SPECIFICATION FOR $\mathrm{U}_{3} \mathrm{O}_{8}$ POWDER FOR MANUFACTURING HFIR FUEL PLATES}

(a) Supplier's manufacturing lot number,

(b) Isotopic Analysis of $\mathrm{U}_{3} \mathrm{O}_{8}$ powder as specified in Section 4.2 .

(c) Chemical purity of $\mathrm{U}_{3} \mathrm{O}_{8}$ powder and trace element content as specified Section 4.3 of this document, and

(d) Physical properties per Section 4.4 of this document.

\subsection{DOCUMENTATION}

All handwritten manufacturing, test, and inspection records shall be in ink. All corrections, changes, or deletions will be done by drawing a single line through the item being changed. The change shall be signed (initials and last name) and dated by the person making the change. All documents furnished shall be an original or a reproducible copy.

\subsection{MATERIAL TRACTABILITY}

All end products and samples shall be traceable to parent material.

\subsection{CLEANLINESS}

The $\mathrm{U}_{3} \mathrm{O}_{8}$ powder shall be dry and free from volatiles, oil and grease. 
ORNL RESEARCH REACTORS DIVISION ENGINEERING STANDARDS ANDD SPECIFICATIONS ORNI/RRD/INT-37//4 RRD-MS-106, R1 Ali l, Page 1

SPECIFICAT!ON FOR U O $_{8}$ POWDER FOR MANUFACTURING HF!R HUEL PLATES

\section{A T T 1}

Y-73834, Particle Shape and Microstructure

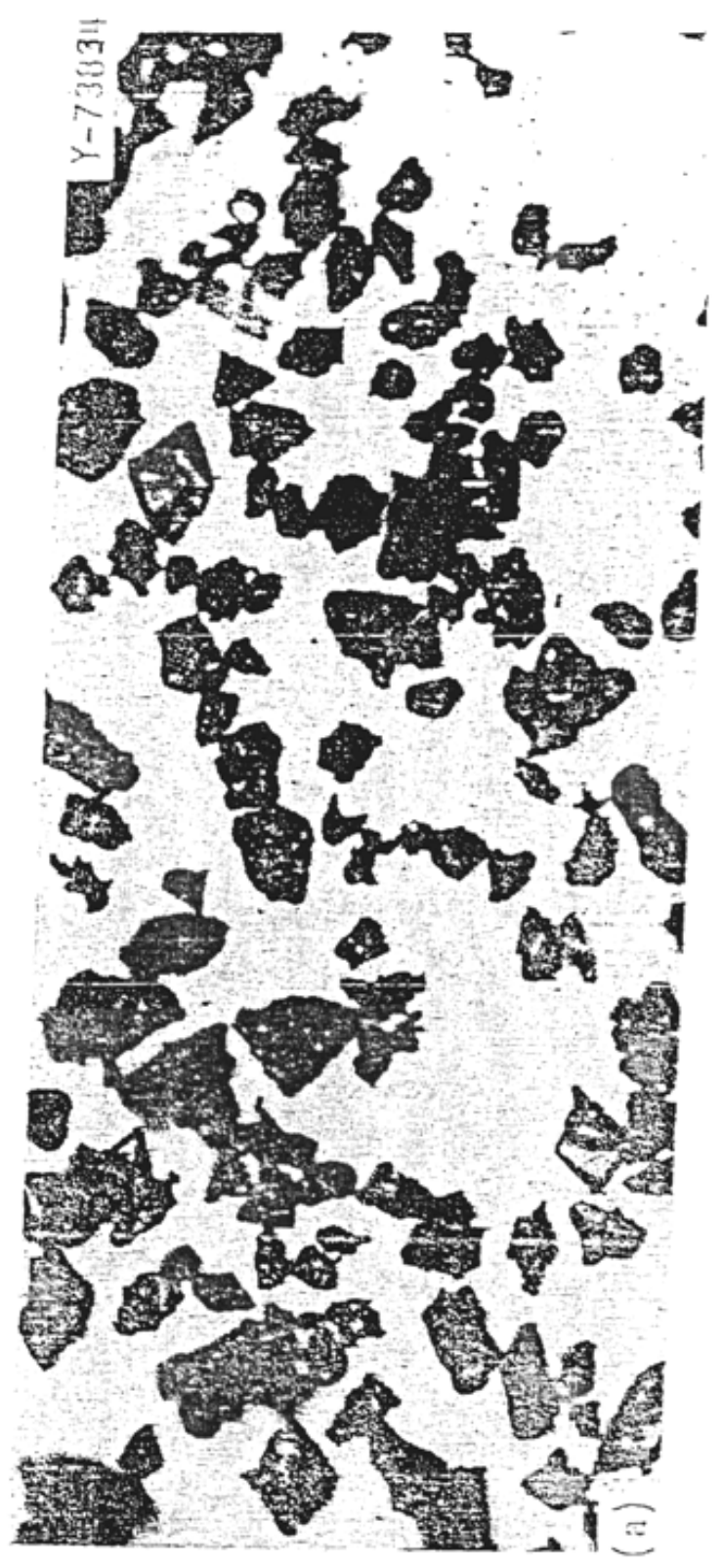


ORNL RESEARCII REACTORS DIVISION ENGINEERING STANDARDS AND SPECIITCATIONS

ORNL/RRI)/INI-37//4

RRI)-MS-106, R1

A íi 2, Page 1

SPECIFICATION TOR $\mathrm{U}_{3} \mathrm{O}_{8}$ POWDER FOR MANLFACIIRING IIIIIIEL

PLATES

ATT 2

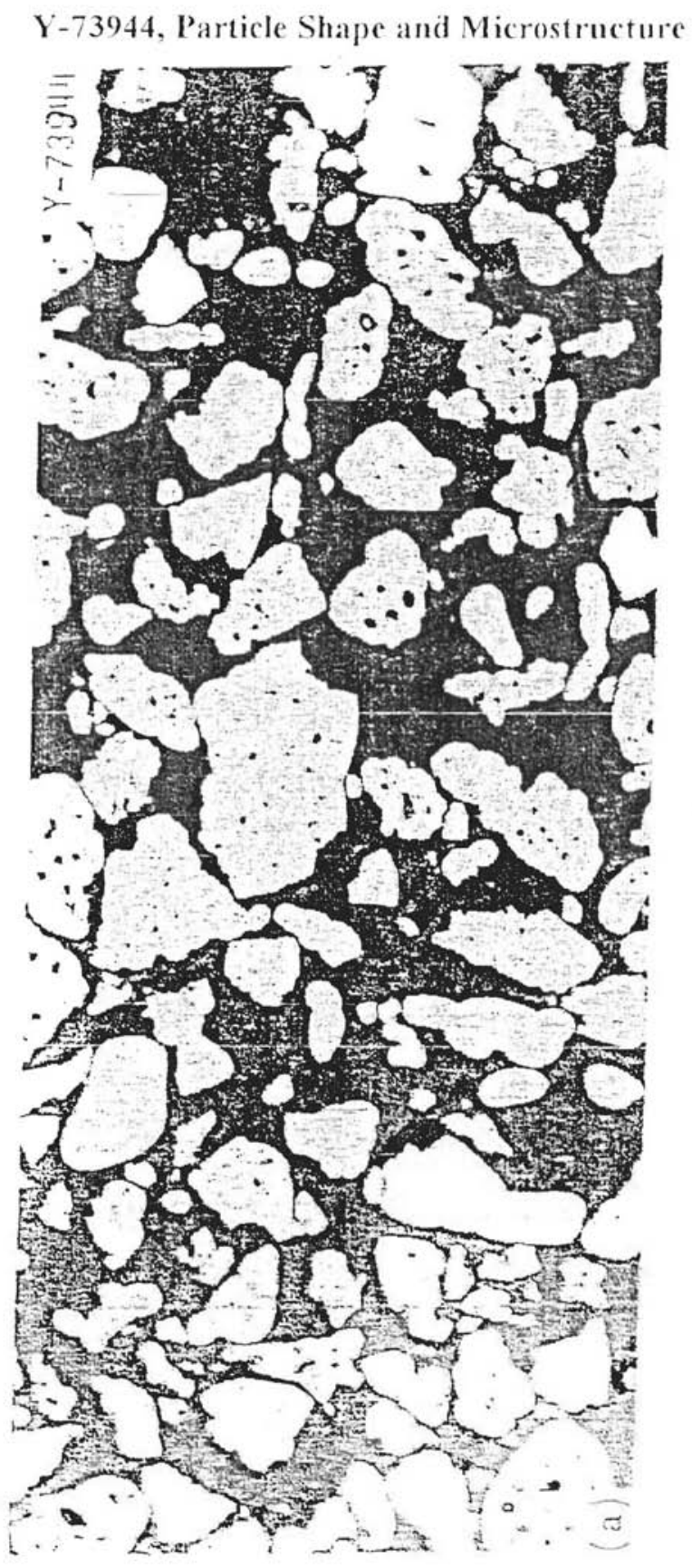




\section{APPENDIX B}

SPECIFICATION FOR THE PRODUCTION OF HFIR HEU FUEL ELEMENTS 
ORNL RESEARCH REACTORS DIVISION

ENGINEERING STANDARDS AND SPECIFICATIONS

ORNLIRRDINT-37N3

HFIR-SS-601

\section{HFIR CORE COMPONENTS}

RRD-FE-3, REV. 3

SPECIFICATIONS FOR

HIGH FLUX ISOTOPE REACTOR FUEL ELEMENTS

Prepared by:

Reviewed by:

Reviewed by:

Reviewed by:

Reviewed by:

Approved by:
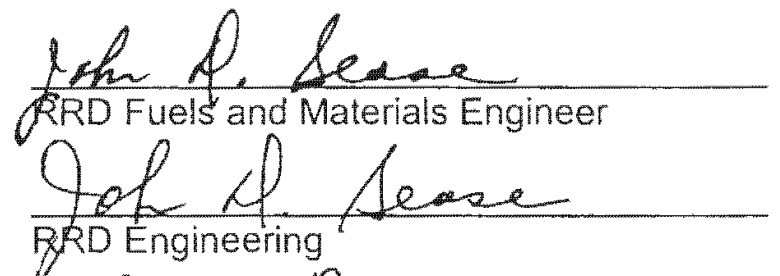

$$
70
$$
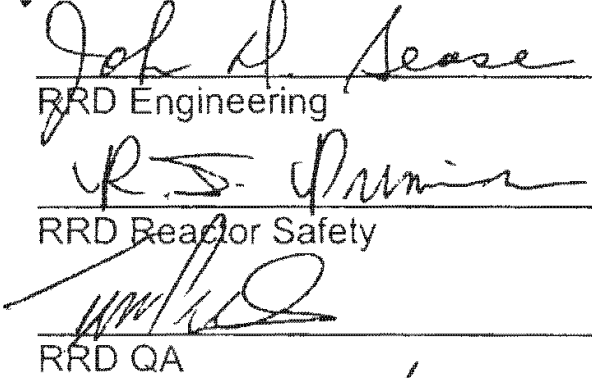

$$
\text { RRDQA }
$$

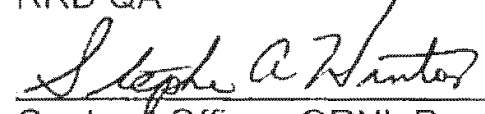

Contrad Officer, ORNL Progurement

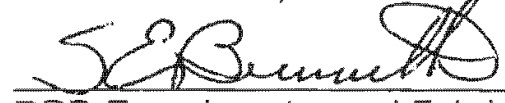

$\overrightarrow{R R D}$ Experimenter and Fabrication Interface Manager

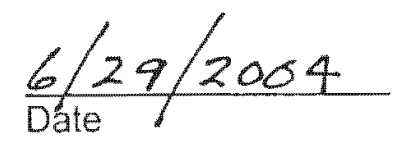

$6 / 29 / 2004$

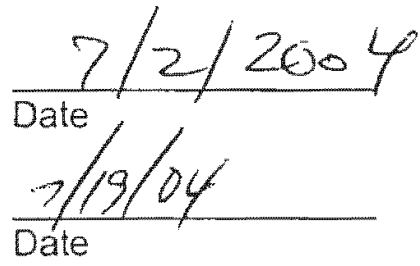

$\frac{7 / 28 / 04}{\text { Date }}$

7.29 .04

Date

Note: Revision to this document may affect ORNL/TM-11656, Safety Analysis Report for Packaging: The ORNL HFIR Unirradiated Fuel Element Shipping Container. 
ORNLIRRDINT $-37 / 3$

HFIR-SS-601. HFIR Core Components

RRD FE-3, Rev. 3

Specification for High Flux Isolope

Reactor Fuel Elements

\section{TABLE OF CONTENTS}

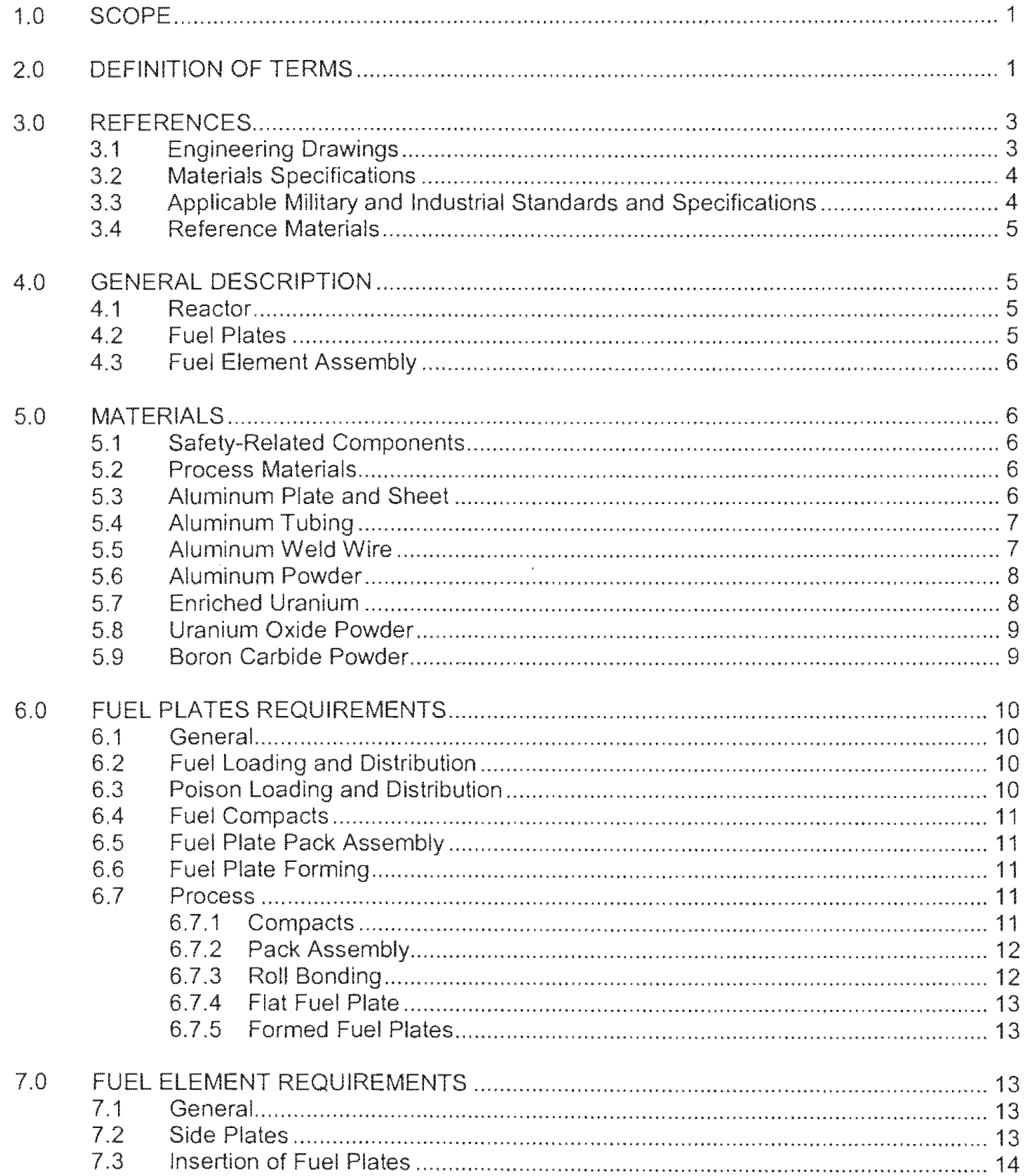


ORNL/RRD/INT-37N3

HFIR-SS-601, HFIR Core Components

RRD-FE-3, Rev, 3

Specification for High Flux Isotope

Reactor Fuel Elements

\section{TABLE OF CONTENTS}

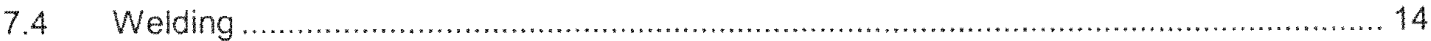

7.4.1 Welding Test Samples ................................................................. 14

$7.4,2$ Welding of Fuel Elements................................................................ 15

7.4 .3 Welding of End Fittings .............................................................. 16

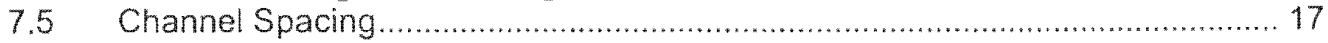

7.6 Element Identification........................................................................... 17

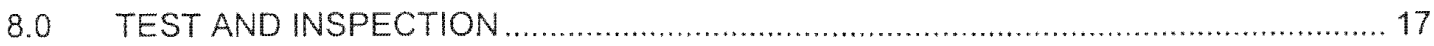

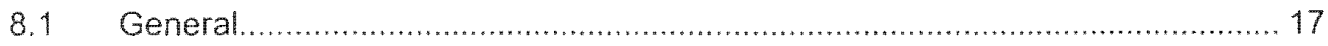

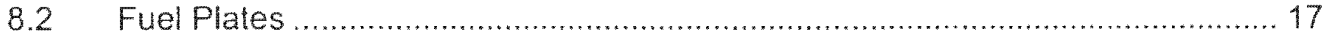

8.2.1 Fuel Loading .............................................................................., 17

8.2 .2 Fuel Core Configuration .............................................................. 18

8.2.3 Fuel Distribution .......................................................................... 18

8.2.4 Fuel Homogeneity ........................................................................ 19

8.2 .5 Boron Distribution.......................................................................... 19

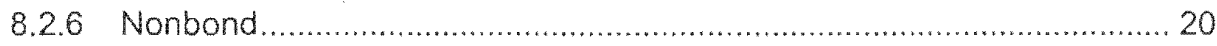

8.2.7 Clad Thickness and Bonding .............................................................20

8.2.8 Radioactive Surface Contamination ............................................... 21

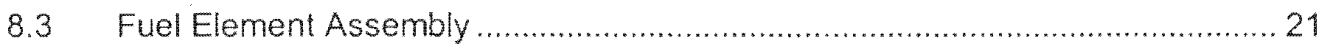

8.3.1 Uranium Loading ........................................................................... 21

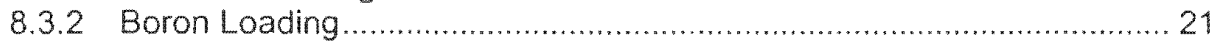

8.3.3 Coolant Channel Spacing …......................................................... 21

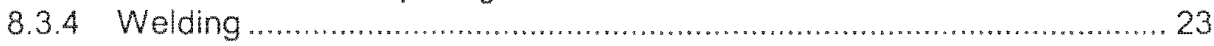

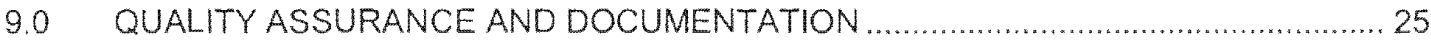

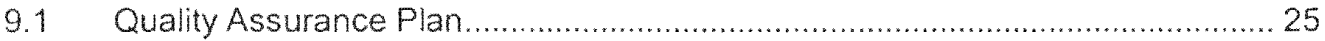

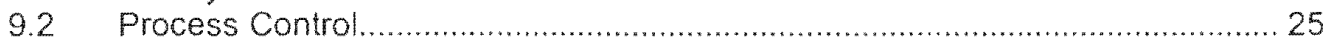

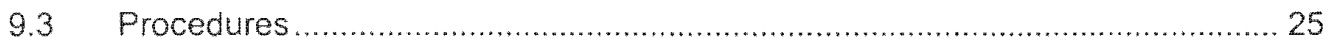

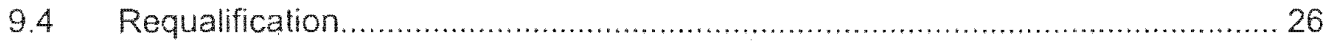

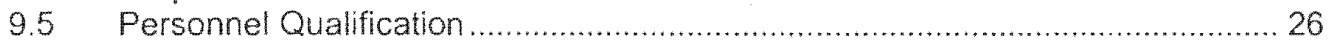

9.5.1 Powder Compacting ..................................................................... 26

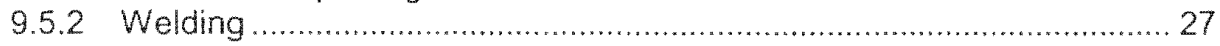

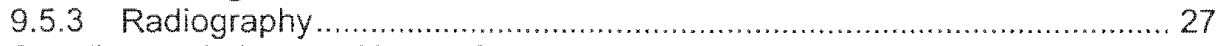

9.6 Supplier Deviation and Nonconformance ….............................................. 27

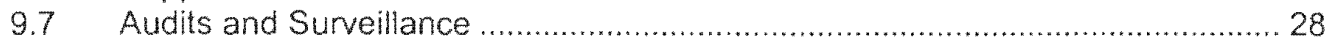

9.7.1 Audits and Source Inspection ....................................................... 28

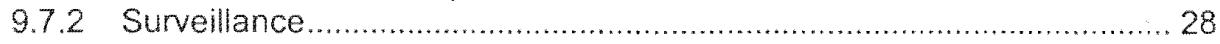

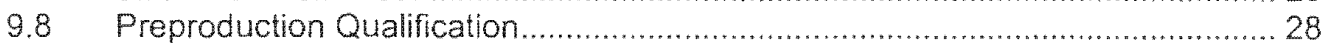

9.8.1 Fuel Plate Qualification ............................................................... 29

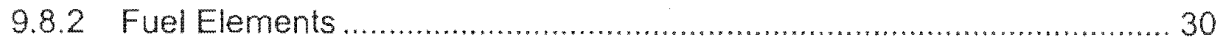

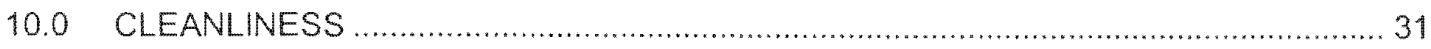

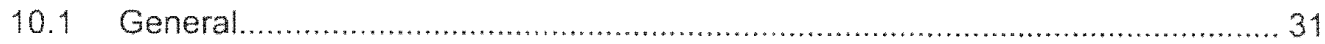

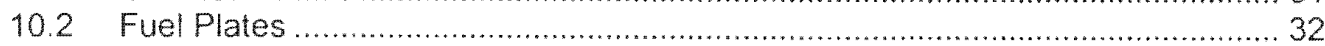

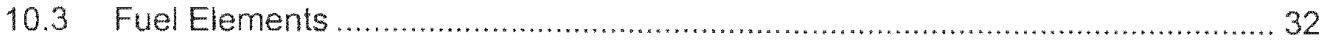


ORNLIRRDINT-37N3

HFIR-SS-601, HFIR Core Components RRD-FE-3, Rev. 3

Specification for High Flux Isotope Reactor Fuel Elements

\section{TABLE OF CONTENTS}

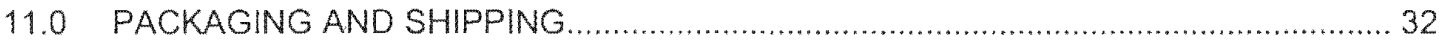

12.0 RECORDS, SAMPLES, AND INFORMATION TO BE SUPPLIED $\ldots \ldots \ldots \ldots \ldots \ldots \ldots \ldots \ldots, 33$

12.1 Engineering and Drawings and Material Specifications .................................... 33

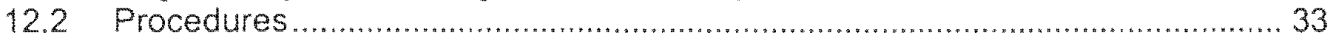

12.3 Production Records ............................................................................. 33

12.4 Safely-Related Materials Certification and Archive Samples........................... 33

12.5 Preproduction Procedure Qualification Results........................................... 34

12.6 Data Fumished with Each Element ............................................................ 34

Appendix A

Cross Reference to BWXT Working Drawings

List of Tables

8.1 Coolant channel spacing tolerances (in.) 


\author{
ORNLIRRDINT -37N3 \\ HFIR-SS-601, HFIR Core Components \\ RRD-FE-3, ReV. 3 \\ Specificalion for High Flux Isotope \\ Reactor Fuel Elements
}

\title{
$1.0 \mathrm{SCOPE}$
}

This specification covers the process and material requirements for the fabrication of fuel assemblies for the High Flux Isotope Reactor (HFIR) at the Oak Ridge National Laboratory (ORNL). The aluminum-plate-type fuel for HFIR is contained in two separate cylindrical elements (inner and outer elements), which are nested inside each other during their operation in the reactor. The requirements for the manufacture of these separate fuel elements (inner and outer elements) are specified in this document. Included in this specification are the requirements for the materials; processes for the fabrication and inspection of components; processes for the assembly, welding, and inspection of elements; and the quality assurance requirements to produce these fuel elements. This specification is the controlling document for the fabrication of HFIR fuel elements and references the requisite ORNL engineering drawings. The specification also includes the preproduction vendor qualification requirements, if the Seller is not currently qualified.

\subsection{DEFINITION OF TERMS}

Average Coolant Channel Thickness. The normal distance between two adjacent fuel plates, measured in a plane perpendicular to the longitudinal axis of the element and averaged along a track (track average) or across the five tracks (station average).

Batch. A quantity of material that can be represented by a single sample.

Certification. A written statement of compliance with an individual requirement of this specification.

Compact. The cold pressed parallelepiped body containing a fuel and a filler section for one fuel plate.

Company. Oak Ridge National Laboratory, operated by current Department of Energy (DOE) contractor.

Company's Technical Representative (CTR). The individual identified by the Company as its representative for all technical issues related to the procurement of fuel elements.

Company's Contract Officer. The individual identified by the Company as its representative for all contractual issues related to the procurement of fuel elements

Coolant Channel. The region between two adjacent fuel plates in an assembled element.

Core Hump. The thickest portion (cross-sectional area) of the fuel section in a fuel core as located on the side of the plate containing the filler section.

Core Outline. The closed figure resulting from drawing a line connecting the outermost particles of $\mathrm{U}_{3} \mathrm{O}_{8}$, as on a radiograph of a flat plate or as revealed in $\mathrm{X}$-ray fluoroscopic examination of a flat fuel plate.

Page 1 of 36 
ORNL/RRD/NT-37N3

HFIR-SS-601, HFIR Core Components

RRD-FE-3, Rev, 3

Specification for High Flux Isotope

Reactor Fuel Elements

Cover Plate. The aluminum plate components of a billet that will make up the cladding or protective portion of the fuel plates.

Dummy Fuel Element. A prototype of a HFIR fuel element that is identical to a HFIR fuel element in materials and dimensions except the fuel plates are replaced with simulated fuel plates made from aluminum sheet stock.

End Adapters. Cylindrical tube-shaped sections welded on the side plate ends to provide a bearing surface for the fuel elements in the reactor.

Frame. The billet component that will provide the aluminum surrounding the fuel core.

Fuel Assembly. The complete fuel loading for HFIR, consisting of an inner and an outer fuel element.

Fuel Core. The rolled formed rectangular parallelepiped section of a fuel plate that is comprised of the fuel and aluminum filler sections.

Fuel Element. A term for either the inner or outer fuel element.

Fuel Plate. The individual uranium-bearing aluminum plate used in either the inner or outer fuel elements.

Fuel Section. The contoured portion of a fuel compact or core containing the $\mathrm{U}_{3} \mathrm{O}_{8}$ particles mixed with aluminum powder.

Filler Section. The aluminum portion of the fuel compact or core that is added to maintain the fuel contour in the cold pressed fuel compact. For the inner element, it contains the burnable poison.

Grooves. The circumferential channels cut into the side plates in which weld metal is deposited to join fuel plates to the side plates.

Lot. Material from a single ingot, or from other comparable starting material (for example, a single group of fuel cores), fabricated successively to a given size by identical procedures.

Pack Assembly. The assembly of two fuel compacts, frame, and cover plates prepared for hot rolling (i.e., billet).

Qualification. A demonstration of the Seller's ability to successfully conduct an operation or test in accordance to this specification and to the satisfaction of the Company.

Reactor. The High Flux Isotope Reactor (HFIR) at the Oak Ridge National Laboratory.

Safety-Related Component. Any HFIR component related to the safely of the reactor as identified in the HFIR Safety Analysis Report. The HFIR fuel elements are safely-related componenis. 
ORNL/RRD/INT $-37 N 3$

HFIR-SS-601, HFIR Core Components

RRD-FE-3, Rev. 3

Specification for High Flux Isotope

Reactor Fuel Elements

Seller. The successful out-source bidder for the manufacture of HFIR fuel elements.

Side Plates. Cylindrical tubes in which the fuel plates are assembled.

Slot. The longitudinal channels cut parallel and uniformly spaced into the surface of the side plates to receive the fuel plates.

Surface Density. The total quantity of uranium or boron contained in a specified volume of a fuel plate that includes both the cladding and the fuel core.

Wall Assurance Groove. Circular grooves cut in the side plates that are used to measure the wall thickness of the side plates after final machining of a fuel element.

Welder. One who performs a manual or semiautomatic welding operation.

Welding Operator. One who operates a machine or automatic welding equipment.

\subsection{REFERENCES}

This specification supersedes HFIR-FE-3 issued in August 1984. The order of precedence of the documents referenced in this specification shall be follows: (1) this document, (2) ORNL engineering drawings, (3) other ORNL/Research Reactors Division (RRD) specifications and procedures, and (4) military and industry standards and specifications.

\subsection{Engineering Drawings}

The engineering drawings listed below are an integral part of this specification. The Company will maintain all listed ORNL engineering drawings. If there is a recognized conflict between this document and an engineering drawing(s), the Company shall be informed in writing by the Seller and the engineering drawing(s) andior this document revised by the Company. The Seller is encouraged to use the applicable revision of the listed drawings for working drawings. If the Seller elects to produce and use working drawing comparable to the listed engineering drawings for use on the shop floor, these working drawings and their revisions shall be approved by the CTR and RRD Engineering for configuration control purposes.

A listing of the applicable ORNL engineering drawings with a cross reference to the comparable approved BWX Technologies, Inc. (BWXT) working drawings currently in use are tabulated in Appendix A. The revision level and issue date of these drawings in effect at the beginning date of a new contract or a later revision of these drawings as agreed to by the Buyer and Seller shall be used. See Appendix A. 
ORNLIRRD/NT $-37 / \mathrm{N}$ HFIR-SS-601, HFIR Core Components

RRD-FE-3, Rev. 3

Specification for High Flux Isolope Reactor Fuel Elements

\begin{tabular}{|c|c|}
\hline & ORNL \\
\hline \multicolumn{2}{|l|}{ ASSEMBLY DRAWINGS } \\
\hline HFIR imner fuel element-assembly & $E-42118$ \\
\hline HFIR outer fuel element-assembly & $E-42126$ \\
\hline \multicolumn{2}{|l|}{ COMPONENT DETALSS } \\
\hline HFIR inner fuel element-fuel plate loading details & $0-42114$ \\
\hline HFIR outer fuel element-fuel plate loading details & $\mathrm{D}-42122$ \\
\hline $\begin{array}{l}\text { HFIR inner fuel element fuel plate-true involute curvature design } \\
\text { details }\end{array}$ & D. 42113 \\
\hline $\begin{array}{l}\text { HFIR outer fuel element fuel plate-true involute curvature design } \\
\text { details }\end{array}$ & $\mathrm{D} * 42121$ \\
\hline HFIR inner fuel element-inner side plate $\# 1$ & $E-42112$ \\
\hline HFIR inner fuel element-outer side plate & $E-42117$ \\
\hline HFIR outer fuel element-inner side plate \#3 & $E-42120$ \\
\hline HFIR outer fuel element-outer side plate 4 & $E-42125$ \\
\hline
\end{tabular}

\subsection{Materials Specifications}

The following materials specification shall be used to procure fuel that will be contained in the finished fabricated HFIR fuel elements:

- RRD-MS -106, Specification for $\mathrm{U}_{3} \mathrm{O}_{3}$ Powder for Manufacturing HFIR Fuel Plates.

Revision in effect on issue date of new contract or later revisions as agreed to by Buyer and Seller.

\subsection{Applicable Military and Industry Standards and Specifications}

The applicable portions of the following documents, as defined herein, form a part of this specification. Where there is conflict between the documents cited and the revisions thereof, the Seller shall notify the Company of the conflict and use the latest revision, in effect at the signing of the contract, unless otherwise directed by the Company.

- 10 CFR 830.10, "Quality Assurance Requirements."

- MIL-C-45662, "Calibration System Requirements."

- EPRI-NP- 5652 "Guideline for the Utilization of Commercial Grade ltems in Nuclear Safely Related Applications."

- ASTM-B-209, "Aluminum and Aluminum-Alloy Sheet and Plate."

- ASTM-B-241, "Aluminum and Aluminum-Alloy Seamless Pipe and Seamless Extruded Tube." 


\author{
ORNLIRRD/INT-37N3 \\ HFIR-SS-601, HFIR Core Components \\ RRD-FE-3, Rev. 3 \\ Specification for High Flux Isotope \\ Reactor Fuel Elements
}

- AWS A5.10, "Specification for Bare Aluminum and Aluminum Alloy Electrodes and Rods."

- ANSIAWS D1.2, "Structural Welding Code-Aluminum."

- ASME Boiler and Pressure Vessel Code, Section VIII, "Pressure Vessels."

- ANSI/ANS-8.21-1995, "Use of Fixed Neutron Absorbers in Nuclear Facilities Outside Reactors."

- SNT-TC-1A, "American Society for Nondestructive Testing (ASNT) Recommended Practice."

\title{
3.4 Reference Materials
}

These reference materials are intended to provide the Seller with general guidance and overview of the HFIR fuel fabrication processes, but are not to be considered as approved procedures or a part of this specification:

- ORNL-TM-11809, "Observations in the Manufacture of Aluminum-Based Research Reactor Fuel Elements," R. W. Knight, July 1993.

- ORNL-TM-6852, "Fabrication Procedures for the Manufacturing of High Flux Isotope Reactor Fuel Elements," R. W. Knight and Ray Morin, December 1999.

- RRAP-4110, "ORNL Research Reactors Division Administrative Policies and Procedures (RRAP) Dedication of Commercial Grade ltems," Rev. 0, June 9, 2000.

\subsection{GENERAL DESCRIPTION}

\subsection{Reactor}

The HFIR is a research-type nuclear reactor that was designed and buit in the early 1960 s and has been in continuous operation since its initial criticality in 1965. Its primary function is to produce neutrons for the production of radioisotopes, materials irradiation, and research. Under current modernization plans, the HFIR is expected to continue in operation until 2035.

The HFIR is a compact (51-L core) flux-trap-type reactor that is light-water moderated and designed to operate at $100 \mathrm{MW}(\mathrm{t})$. The reactor is currently being operated at $85 \mathrm{MW}(\mathrm{t})$. The very high-power-density core $(-2000 \mathrm{~kW} / \mathrm{L})$ uses two nested, cylindrical aluminum (Al) platetype fuel elements and a beryllium reflector that surrounds the core. The power of the highneutron-leakage core is controlled by a reflector control system. The maximum unperturbed thermal neutron flux in HFIR is $-5 \times 10^{15}$ neutrons $/\left(\mathrm{cm}^{2}-\mathrm{s}\right)$.

The inner and outer fuel elements, which comprise the HFIR core, consist of annular arrays of fuel plates contained in slotted sections of aluminum tubing (side plates). The inner element contains 171 identical fuel plates and the outer 369 , which are also identical but differ slightly from those contained in the inner element.

\subsection{Fuel Plates}

The aluminum fuel plates are made by the "picture frame" hot roll bonding process. The loading of the highly enriched $\left(93 \%{ }^{235} \mathrm{U}\right) \mathrm{U}_{3} \mathrm{O}_{8}$ fuel powder is continuously varied across the width of the fuel plates (graded) by pressing a duplex powder compact. In this duplex compact, the fuelbearing powder is contoured by using a sweep template and pure aluminum filler powder added

Page 5 of 36 
ORNLURRDINT-37N3

HFIR-SS-601, HFIR Core Components

RRD-FE-3, Rev. 3

Specification for High Flux Isotope

Reactor Fuel Elements

on top of the contoured fuel powder before pressing. These compacts are loaded into aluminum frames with covers for hot roll bonding. In the rolled plates, the maximum fuel loading is approximately along the longitudinal centerline with reduced fuel loading along the edges to reduce powder peaking. In the fuel plates for the inner elements, a burnable poison $\left({ }^{80} \mathrm{~B}\right)$ contained in natural boron as $\mathrm{B}_{4} \mathrm{C}$ powder is included with the aluminum filler powder during the compacting operation. The fuel plates are formed into an involute configuration to provide the maximum fuel volume with the graded fuel distribution, uniform metal-to-water ratio, and high heat transfer surface-to-core-volume ratio, while maintaining a constant channel spacing.

\subsection{Fuel Element Assembly}

Each fuel element is assembled by inserting the formed fuel plates into machined slots in two concentric cylindrical side plates. The fuel plates are attached along both edges in 1 -in. intervals to the side plates by depositing weld metal by the gas metal arc welding (GMAW) process in a circumferential groove machined into the side plates. After welding, the outside and inside surfaces of the end attachment area on the elements are rough machined and cylindrical end adapters attached by a GMAW process before final machining.

\subsection{MATERIALS}

\subsection{Safety-Related Components}

HFIR fuel elements are safety-related components and must meet all RRD requirements for such components. The procurement by the Seller of any commercial-grade raw materials that will be incorporated in the final element assembly must be procured and controlled in a manner similar to the requirements as outlined in EPRI-NP- 5652, "Guideline for the Utilization of Commercial Grade liems in Nuclear Safety Related Applications." The dedication program as presented in RRAP-4110 or the Seller's equivalent program shall be used for the procurement of all commercial materials used in the fabrication of HFIR fuel elements.

\subsection{Process Materials}

All materials used in the fabrication of the HFIR fuel elements that are not part of the final fuel element shall be procured with the Seller's specifications. This shall include welding gases, all cleaning materials, cutting fluids, lubricants, solvents, or fixture materials that come in contact with any component used in the fuel element during manufacturing. The shielding gases for welding aluminum shall conform to the requirements as specified in ANSI/AWS-D1.2, Section 1.3 .3 (welding-grade argon shall have a minimum purity of $99.998 \%$ with a dew point of $-76^{\circ} \mathrm{F}$ or lower), and it shall be certified by the Seller that the gases used conform to these requirements.

\subsection{Aluminum Plate and Sheet}

The aluminum plate and sheet shall be procured as commercial aluminum alloy 6061 -T0 and be certified to meet the requirements of ASTM B-209. Additional analysis shall be performed and reported on the following list of elements. These elements are the only ones to be included in the "others each" category referenced within the material specification. The "others total" category shall be simply reported as the calculated sum of the analytical results reported on the

Page 6 of 36 
ORNL/RRD/NT-37N3

HFIR-SS-601. HFIR Core Components

RRD-FE-3, Rev. 3

Specification for High Flux Isotope

Reactor Fuel Elements

following list of elements and shall be considered acceptable when less than or equal to the "others total" limit. The trace elements to be analyzed for and the maximum values allowed are listed below:

* Boron, $\leq 10 \mathrm{ppm}$

- Cadmium, $\leq 30$ ppm

- Lithium, $\leq 80 \mathrm{ppm}$

- Gallium, $\leq 400 \mathrm{ppm}$

- Cobalt, $\leq 10 \mathrm{ppm}$

The material may be procured in the T-6 temper and heat treated as appropriate by the Seller.

\subsection{Aluminum Tubing}

The aluminum tubes shall be procured as commercial extruded aluminum alloy 6061-T6511 tubes and be certified to meet the requirements of ASTM B-241. Additional analysis shall be performed and reported on the following list of elements. These elements are the only ones to be included in the "others each" category referenced within the material specification. The "others total" category shall be simply reported as the calculated sum of the analytical results reported on the following list of elements and shall be considered acceptable when less than or equal to the "others total" limit. The trace elements to be analyzed for and the maximum values allowed are listed below:

- Boron, $\leq 10 \mathrm{ppm}$

- Cadmium, $\leq 30$ ppm

- Lithium, $\leq 80 \mathrm{ppm}$

- Gallium, $\leq 400 \mathrm{ppm}$

- Cobalt, $\leq 10 \mathrm{ppm}$

The T-6511 temper is required for the side plate tubes to meet final machining tolerances in the fuel elements and may not be waived.

\subsection{Aluminum Weld Wire}

The aluminum weld wire used in the attachment of fuel plates and end adapters shall be procured as commercial aluminum alloy 4043 and be certified to meet the requirements of AWS A5.10. The diameter of the weld wire shall be nominally $0.030 \mathrm{in}$. Additional analysis shall be performed and reported on the following list of elements. These elements are the only ones to be included in the "others each" category referenced within the material specification. The "others total" category shall be simply reported as the calculated sum of the analytical results reported on the following list of elements and shall be considered acceptable when less than or equal to the "others total" limit. The trace elements to be analyzed for and the maximum values allowed are listed below:

- Boron, $\leq 10 \mathrm{ppm}$

- Cadmium, $\leq 30 \mathrm{ppm}$

- Lithium, $\leq 80 \mathrm{ppm}$ 
ORNL/RRD/NT-37N3

HFIR-SS-601, HFIR Core Components

RRD-FE-3, Rev. 3

Specification for High Flux Isotope

Reactor Fuel Elements

- Gallium, $\leq 400 \mathrm{ppm}$

- Cobalt, $\leq 10 \mathrm{ppm}$

\subsection{Aluminum Powder}

The aluminum powder shall be atomized particles of 101 aluminum. One hundred percent of the powder shall pass through a 100 mesh U.S. standard screen with $75-85 \%$ passing through a 325 mesh U.S. standard screen. The referenced micron sizes as determined by Fisher SubSieve Sizer (F.S.S.S.) are as follows:

- $\quad<10$ microns (D10) $10.8 \%$

- $<50$ microns (D50) $30.6 \%$

- $\quad<90$ microns (D90) $82.8 \%$

Aluminum powder manufactured by Toyal America, Inc., (ATA 101 aluminum powder or equivalent) is the type powder required. The aluminum powder shall be dry and free from volatiles, oil, and grease and meet the chemical requirements listed below.

\begin{tabular}{ll}
\hline Element & Weight percent \\
\hline Aluminum (metalic) & 99.30 minimum \\
Cadmium & 0.002 maximum \\
Copper & 0.200 maximum \\
Lithium & 0.008 maximum \\
Silicon and iron & 0.250 maximum \\
Zinc & 0.100 maximum \\
Other (single) & 0.050 maximum \\
$\mathrm{Al}_{2} \mathrm{O}_{3}$ & 0.700 maximum \\
$\mathrm{Boron}$ & 0.001 maximum \\
\hline
\end{tabular}

An aluminum powder lot shall represent one continuous production run and variations between individual containers shall be minimal. An aluminum powder lot shall nol be accepted for production use until the Seller has demonstrated that the candidate powder lot will perform satisfactorily in the fuel plate fabrication process by meeting the requirements of this specification.

\subsection{Enriched Uranium}

The enriched uranium feed material shall contain $92-94 \%{ }^{235} \mathrm{U}$ in total $U$. The Seller shall have a nuclear criticality safety program approved by the Nuclear Regulatory Commission (NRC) or DOE to prevent the possibility of a nuclear criticality accident during manufacture and storage of all fuel powders, components, assemblies, and scrap. As a part of this program, the Seller shall

Page 8 of 36 
ORNL/RRD/NT-37N3

HFIR-SS-601, HFIR Core Components

RRD-FE-3, Rev. 3

Specification for High Flux Isotope

Reactor Fuel Elements

ensure that an assembled inner fuel element at any stage in manufacture or storage is never inserted into the annulus of an outer fuel element.

\subsection{Uranium Oxide Powder}

The special $\mathrm{U}_{3} \mathrm{O}_{2}$ powder used in the compacts is a -170 mesh (U.S. standard mesh size) powder procured to meet the requirements as specified in RRD specification RRD-MS-106, "Specification for $\mathrm{U}_{3} \mathrm{O}_{8}$ for Manufacturing HFIR Fuel Plates." The physical properties of this powder is extremely important to the homogeneity inspection of fuel plates and must be precisely controlled.

\subsection{Boron Carbide Powder}

The boron carbide powder shall have the chemical composition of $\mathrm{B}_{4} \mathrm{C}$ produced from natural boron and be $100 \%-325$ U.S. standard mesh size or equivalent powder. The boron carbide powder shall be dry and free from volatiles, oil, and grease and meet the chemical requirements listed below.

\begin{tabular}{l|cc}
\hline \multirow{2}{*}{ Element } & Concentration (weight \%) & \\
\cline { 2 - 3 } & Minimum & Maximum \\
\hline Boron & 76.5 & \\
Carbon & 20 & 22 \\
Boron plus carbon & 98 & 99.5 \\
$\mathrm{~B}_{2} \mathrm{O}_{3}$ & & 0.2 \\
Soluble boron & & 0.5 \\
Iron & & 0.5 \\
Aluminum & & 0.2 \\
Calcium & & 0.1 \\
Magnesium & & 0.05 \\
Moisture & & $200 \mathrm{ppm}$ \\
${ }^{10} \mathrm{~B}$ & 18.22 & 18.78 \\
\hline
\end{tabular}

A powder lot shall represent one continuous production run, and variations between individual containers shall be minimal. The analytical laboratory and test methods used to certify the boron and ${ }^{10} \mathrm{~B}$ content shall satisfy the requirement of ANSU/ANS-8.21. Section 5.3 .1 .3 , for $\mathrm{B}_{4} \mathrm{C}$ purchased subsequent to June $30,1999$.

Page 9 of 36 
ORNLIRRDINT-37N3

HFIR-SS-601, HFIR Core Components

RRD-FE-3, Rev. 3

Specification for High Flux Isotope

Reactor Fuel Elements

\subsection{FUEL PLATES REQUIREMENTS}

\subsection{General}

The fuel plates shall be manufactured to the requirements as specified in the following ORNL engineering drawings:

- D-42114, "HFIR Inner Fuel Element-Fuel Plate Loading Details."

- D-42113, "HFIR Inner Fuel Element Fuel Plate-True Involute Curvature Design Details."

- D-42122, "HFIR Outer Fuel Element-Fuel Plate Loading Details."

- D-42121, "HFIR Outer Fuel Element Fuel Plate-True Involute Curvature Design Details."

The applicable revision levels for these drawings are shown in Section 3.1.

\subsection{Fuel Loading and Distribution}

The ${ }^{235} \mathrm{U}$ contained in $\mathrm{U}_{3} \mathrm{O}_{8}$ powder particles shall be loaded in each compact as follows:

- Inner-15.18g $\pm 0.150 \mathrm{~g}^{235} \mathrm{U}$

- Outer-18.44g $\pm 0.180 \mathrm{~g}^{235 \mathrm{U}}$

The relative concentration of fuel across the width of each plate shall be varied as specified in the fuel contour diagrams and accompanying tables in the following ORNL engineering drawings:

- D-42114, "HFIR Inner Fuel Element-Fuel Plate Loading Details."

- D-42122, "HFIR Outer Fuel Element-Fuel Plate Loading Details."

Straight-line interpolation of the values shown the tables in the referenced drawings may be used for additional " $Y$ "values.

The ${ }^{235} \mathrm{U}$ surface density shall be calculated by multiplying the relative " $Y$ " values shown in the tables by the following factors:

- Inner-0.0459

* Outer-0.0683

The fuel homogeneity requirements are specified in Section 8.2 .4 .

\subsection{Poison Loading and Distribution}

The ${ }^{10} \mathrm{~B}$ contained in natural boron carbide powder shall be loaded in each inner fuel plate as follows:

- Inner-0.0164 g $\pm 0.0016 \mathrm{~g}-{ }^{10} \mathrm{~B}$

- Outer-None required 
ORNLIRRD/NT $-37 / N 3$

HFIR-SS-601, HFIR Core Components

RRD FE-3, Rev. 3

Specificalion for High Flux Isotope

Reactor Fuel Elements

The relative concentration of the boron across the width of each inner fuel plate shall be varied as specified in the fuel contour diagram and accompanying table shown in ORNL engineering drawing D-42114, "HFIR Inner Fuel Element-Fuel Plate Loading Details." Straight-line interpolation may be used for additional " $Z$ " values.

The boron surface density shall be calculated by multiplying the relative " $A$ " values shown in the table in the referenced drawing by the following factor: $2.27 \times 10^{-5}$.

The boron homogeneity requirements are specified in Section 8.2.5.

\subsection{Fuel Compacts}

Fuel compact shall be made by a powder metallurgical process to meet the fuel core configuration as specified in the following engineering drawings:

- D-42114, "HFIR Inner Fuel Element-Fuel Plate Loading Details."

- D-42122, "HFIR Outer Fuel Element-Fuel Plate Loading Details."

\subsection{Fuel Plate Pack Assembly}

The pack assembly for roll forming shall be fabricated to meet the fuel plate configuration as specified in the following engineering drawings.

- D-42114, "HFIR Inner Fuel Element-Fuel Plate Loading Details,"

- D-42122, "HFIR Outer Fuel Element-Fuel Plate Loading Details."

\subsection{Fuel Plate Forming}

The fuel plates shall be formed as specified in the following ORNL engineering drawings:

- D-42113, "HFIR Inner Fuel Element Fuel Plate-True Involute Curvature Design Details."

- D-42121, "HFIR Outer Fuel Element Fuel Plate-True Involute Curvature Design Details."

\subsection{Process}

The picture frame hot-roll bonding process shall be employed to fabricate the fuel plates.

\subsubsection{Compacts}

1. A sequential number including lot number shall be assigned to each fuel compact, and this number shall be used to identify an individual plate throughout manufacturing.

2. The aluminum, $\mathrm{U}_{3} \mathrm{O}_{8}$, and boron carbide (inner only) powder contents for each compact shall be separately dispensed by weight using calibrated scales capable of measuring to $\pm 0.01 \mathrm{~g}$ for the aluminum and $\mathrm{U}_{3} \mathrm{O}_{8} ;$ to $\pm 0.001 \mathrm{~g}$ for the boron carbide. The actual weight dispensed shall be recorded to $0.01 \mathrm{~g}$ for the aluminum and $\mathrm{U}_{3} \mathrm{O}_{8} ;$ and to $0.001 \mathrm{~g}$ for the boron.

Page 11 of 36 
ORNLIRRD/NT -37N3

HFIR-SS-601, HFIR Core Components

RRD $-F E-3$, Rev. 3

Specification for High Flux Isotope

Reacior Fuel Elements

3. After pressing, the weight of each compact before annealing shall be separately measured using calibrated scales capable of measuring to $\pm 0.01 \mathrm{~g}$ and recorded.

\subsubsection{Pack Assembly}

1. The compacts shall be inserted into the frames with clean stainless steel tongs to avoid the introduction of any foreign materials on the bonding surfaces of the frame and covers.

2. The compact identification numbers shall be transferred to the pack assembly by vibratool marking on the top cover plate. The placement of this number shall also be used to establish the reference edge and top and bottom ends of the finished fuel plates.

3. The clamping pressure of the pack assembly for welding shall be sufficient to minimize gaps between the frame and covers prior to and during pack welding.

4. The welding parameters for welding the covers to the frame shall be established to provide a structural weld that will minimize the relative movement of the covers with the frame during hot bonding.

\subsubsection{Roll Bonding}

1. The hot rolling shall be performed at $490^{\circ} \mathrm{C} \pm 10^{\circ} \mathrm{C}\left(914^{\circ} \mathrm{F} \pm 18^{\circ} \mathrm{F}\right)$. A hot rolling schedule shall be established to ensure that the packs/plates are at the specified temperature prior to each hot rolling pass. The thickness after hot roll (nominally $0.063 \mathrm{in}$.) shall be within $\pm 0.001 \mathrm{in}$.

2. After hot rolling, each plate shall be heat treated (blister anneal) at $490^{\circ} \mathrm{C} \pm 10^{\circ} \mathrm{C}\left(914^{\circ} \mathrm{F}\right.$ $\pm 18^{\circ} \mathrm{F}$ ) for a minimum of 2 hours at the specified temperature to enhance the visual detection of blisters that may be present.

3. The cold rolling shall be at room temperature and provide a roll reduction of nominally $20 \%$. The final thickness shall be adequate to allow for final etching per Section 6.7.5. After cold rolling, the thickness variation in a plate lot of 24 plates shall not exceed 0.001 in.

4. After cold rolling, each plate shall be program annealed between aluminum flattening platens at $490^{\circ} \mathrm{C} \pm 10^{\circ} \mathrm{C}\left(914^{\circ} \mathrm{F} \pm 18^{\circ} \mathrm{F}\right.$ ) for a minimum of 2 hours (time the plates are at the specified temperature) and then cooled at a rate not to exceed $10^{\circ} \mathrm{C} / \mathrm{min}\left(18^{\circ} \mathrm{F} / \mathrm{min}\right)$ to $200^{\circ} \mathrm{C}\left(392^{\circ} \mathrm{F}\right)$. The stack shall be allowed to $\mathrm{cool}$ to $<60^{\circ} \mathrm{C}\left(<140^{\circ} \mathrm{F}\right)$ before removing the platens. The plates shall be annealed with a minimum of 48 and maximum of 144 plates in a single furnace load (maximum of six lots in two stacks).

Page 12 of 36 


\author{
ORNLIRRDINT $-37 / N 3$ \\ HFIR-SS-601, HFIR Core Components \\ RRD-FE-3, Rev. 3 \\ Specification for High Flux Isotope \\ Reactor Fuel Elements
}

\title{
6.7.4 Flat Fuel Plate
}

The configuration of the fuel core for compliance with the applicable engineering drawings shall be determined during fabrication using a template that will outline the maximum and minimum dimensions of the fuel core when examined under a fluoroscope or digital radiographic examination.

The location of the "hump" or line of maximum fuel content in the fuel core to the referenced edge shall be verified by a nondestructive testing method approved by the Company.

\subsubsection{Formed Fuel Plates}

The fuel plates shall be formed to the required involute contour as specified in ORNL engineering drawings by a rubber-pad forming process.

After forming and prior to assembly, each fuel plate shall be etched in a cold solution of $\mathrm{HNO}_{3}-\mathrm{HF}$ followed by a deionized water rinse to remove the oxide film formed during processing (see Section 10 for cleaning requirements). Based on the elching of coupons (prepared from the scrap generated when the HFIR fuel plates are blanked) to establish the etching time, each fuel plate shall be etched to remove a minimum of $0.0001 \mathrm{in}$. per side and to meet the thickness requirements of drawing D-42114 for the outer plates and drawing D-42122 for the inner plates. Pickle and etch baths shall be tested at the beginning of each working day by placing a coupon in the solution to check the strength of the bath. All pickled and etched assemblies shall be handled with clean nylon, cotton, or vinyl gloves.

\subsection{FUEL ELEMENT REQUIREMENTS}

\subsection{General}

The fuel elements shall be manufactured to the requirements as specified in the following ORNL engineering drawings:

- E-42118, "HFIR inner Fuel Element-Assembly."

- E-42126, "HFIR Outer Fuel Element-Assembly."

The handling of plates and assembled elements shall be with clean nylon, cotton, or vinyl gloves. No liquid other than deionized water or clean alcohol may be used in assembly, machining, or cleaning of assembled fuel elements during fabrication and storage. During handling and storage, fuel plates and elements shall be protected from dust, dirt, shop grease, moisture, and other similar contaminants. Elements and fuel plates shall be stored at room temperature.

\subsection{Side Plates}

Side plates for elements shall be machined and inspected in accordance with the following ORNL engineering drawings:

Page 13 of 36 
ORNLIRRO/NT-37N3

HFIR-SS-601, HFIR Core Components

RRD -FE-3, Rev. 3

Specification for High Flux Isotope

Reactor Fuel Elements

- E-42112, "HFIR Inner Fuel Element-Inner Side Plate \#1."

- E-42117, "HFIR Inner Fuel Element-Outer Side Plate \#2."

- E-42120, "HFIR Outer Fuel Element-Inner Side Plate \#3."

- E-42125, "HFIR Outer Fuel Element-Outer Side Plate \#4."

\section{3 insertion of Fuel Plates}

1. The number and location of each fuel plate shall be verified before insertion.

2. Clean isopropyl or ethyl alcohol shall be used as a lubricant during the insertion of a plate into the side plates.

3. A fuel plate that does nol slide freely into a slot shall be removed and replaced with another fuel plate that will slide freely. Force other than the slight hand pressure necessary to slide a plate into a lubricated slot is not permilted during the insertion of a fuel plate.

4. As assembled, each plate shall protrude into the weld groove to meet the plate protrusion requirements at welding specified in section 7.4.2.3.

5. Teflon spacers shall be inserted into each channel after assembly to aid in maintaining the coolant channel spacing during welding.

\subsection{Welding}

The attachment of fuel plates and end fittings shall be as specified in ORNL engineering drawings:

- E- 42118, "HFIR Inner Fuel Element-Assembly."

- E- 42126, "HFIR Ouler Fuel Element-Assembly."

Welds shall be machine-made welds by the GMAW process using fixtures, a positioner for holding and rotating the element during welding, a programmable welding power supply, and automatic filler wire feeder head. A welding procedure specification (WPS) in accordance with ANSI/AWS D1.2-9, Section 4, Part C, or other qualified procedure specifications may be used with the approval of the Company. The weld parameters of voltage, current, rotation speed, wire feed rate, and cover gas flow rate shall be controlled to the extent practical by automatic machine functions. The actual welding parameters used for each weld shall be recorded. The real-time recording of weld parameters is desirable but not mandatory. The Company shall approve the welding equipment, procedures, and inspection methods.

\subsubsection{Weld Test Samples}

1. Weld test samples shall be prepared from sections of each type of side plate; and weld and tensile test plates shall also be prepared. The side plate sections used shall be $\sim 3$ in. wide and contain three weld grooves, with one weld groove in the center of the section. The arc length of the side plate weld test sections shall be as follows: Side Plate 1, $\sim 180^{\circ}$; Side Plate 2, $\sim 180^{\circ}$; Side Plate $3, \sim 120^{\circ}$; Side Plate $4, \sim 72^{\circ}$. The weld 
ORNLIRRDINT -37N3

HFIR-SS-601, HFIR Core Components

RRD-FE-3, ReV. 3

Specification for High Flux Isotope

Reactor Fuel Elements

and tensile test plates, which will simulate the heat dissipation of actual fuel plates during welding, shall be made from the scrap generated when HFIR fuel plates are blanked to size. The weld test plates shall be $-21 / 2 \mathrm{in}$. wide and $1 \mathrm{in}$. long with the wide side parallel to the rolling direction in the scrap. The tensile test plates shall be $-2 \mathrm{in}$. wide and $13 / 4 \mathrm{in}$. long, with the wide side parallel to the rolling direction in the scrap; a hole shall be drilled or punched in one end for attachment to a tensile testing device.

2. In the assembly of a weld test sample, the wide side of the test plates shall be inserted into the slots and bottomed. A minimum of three tensile test plates shall be used in each weld test sample, one in the center slot of the section and with the other two approximately equal distances from the center and the ends. The design of the components for weld test samples is to be approved by the CTR.

3. For each fuel element, a weld test sample representative of either an inner or outer side plate weld shall be made and tested before and/or after (from preceding element) welding the plates into the side plates. Weld test samples shall be welded in the center weld groove with the weid parameters used in the actual welding of the fuel elements. These samples shall contain the startoverlap area and termination point of the weld. Evaluation of a weld test sample shall include visual and pull testing to determine the attachment strength of the weld tensile test plates.

4. Metallographic examination of a section along the centerline of the weld bead of each weld test sample shall be made to evaluate possible variations in the weld penetration that could result from subile changes in the welding machine/wire feed functions over time. The section for metallographic examination shall be polished and etched as required for reviewing.

5. The "after" weld sample from the preceding element of the same type may be used for the "before" weld sample for the next element provided there is not a delay of over 30 working days between welds.

\subsubsection{Welding of Fuel Plates}

1. Welding of a fuel element shall not begin until the before-weld test sample meets the visual and tensile strength requirements in Sections 8.3.4.1 and 8.3.4.2.

2. Before welding, each element shall be visually inspected for alignment of plates, excessive oxidation, and cleanliness.

3. Before welding, the protrusion of the fuel plates into the weld grooves of the side plates shall be determined by measuring the plate penetration at a minimum of three locations: in the middle weld groove and weld grooves on both ends. For outer side plates, the penetration shall be $\geq 0.035$ in; inner side plates $\geq 0.015$ in. During the entire welding operation, the fuel plate penetration shall be a minimum of $0.025 \mathrm{in}$. for outer side plates and $0.010 \mathrm{in}$. for the inner side plates.

4. Assembled elements shall be dried at $121^{\circ} \mathrm{C} \pm 6^{\circ} \mathrm{C}\left(250^{\circ} \mathrm{F} \pm 10^{\circ} \mathrm{F}\right)$ for a minimum of 4 hours to remove residual alcohol or moisture before welding.

Page 15 of 36 
ORNLIRRE/NT-37N3

HFIR-SS-601, HFIR Core Components

RRD-FE-3, Rev. 3

Specification for High Flux Isotope

Reactor Fuel Elements

5. The welds shall be made in a specified sequence starting in the middle and working toward each end.

6. During welding, the direction of the rotation of a fuel element when mounted on the element positioner as observed from the non-geared end of the positioner shall be as follows: (a) inner element, counterclockwise and (b) outer element, clockwise.

7. Adjacent welds shall be started at least $30^{\circ}$ displaced from the overlap area of the previous adjacent weld.

8. The welds shall not extend inio the water channels. The water channels shall be visually inspected for weld "drop-through" and a Supplier Nonconformance Report (SNR; Section 9.6) submitted if any weld "drop-through" extends into the water channel more than $0.010 \mathrm{in}$.

9. Weld filler metal deposits in the weld grooves shall be sufficient to provide a smooth surface after final machining.

10. The face side of each weld shall be free of defects such as cracks, incomplete fusion, or voids. The weld beads shall have a uniform contour and be free of oxidation, and the termination craters shall have a depth less than that required to provide a smooth surface on the fuel element after final machining.

11. To examine the quality of an as-welded external weld bead, it is permissible to machine, grind, or file (using carbon steel tooling) a weld below the surface of the as-welded tubing provided a smooth surface can be achieved after final machining.

12. Repair of surface weld defects such as craters or underfill is permissible by approved procedures. Weld defects that may require removal of weld metal to the weld root shall be submitted on an SNR. The SNR shall include the proposed weld repair procedure and shall be approved by the CTR and RRD QA.

13. The root side of each weld shall be free of gross oxidation, sagging, or warpage.

\subsubsection{Welding of End Fittings}

1. Before welding, each joint shall be visually inspected for alignment, excessive oxidation, and cleanliness.

2. The end fitting welds shall penetrate the full thickness of the side plate.

3. Weld filler metal in the weld grooves shall be sufficient to provide a smooth surface after final machining.

4. The face side of the weld shall be free of defects such as cracks, incomplete fusion, or voids. The weld bead shall have a uniform contour and be free of oxidation, and the 
ORNL/RRD/NT-37N3

HFIR-SS-601, HFIR Core Components

RRD-FE-3, Rev. 3

Specification for High Flux Isolope

Reactor Fuel Elements

termination craters shall have a depth less than that required to provide a smooth surface after final machining.

5. To examine the quality of an as-welded external weld bead, it is permissible to machine, grind, or file (using carbon steel tooling) a weld below the surface of the as-welded tubing provided a smooth surface can be achieved after final machining.

6. Repair of surface weld defects such as craters or underfill is permissible by approved procedures. Weld defects that may require removal of weld metal to the weld root shall be submitted on an SNR. The SNR shall include the proposed weld repair procedure and shall be approved by the CTR and RRD QA.

\subsection{Channel Spacing}

The coolant channel spacing shall be measured before the welding of the end fitings and final machining.

\subsection{Element Identification}

Each element shall be marked as specified on the element assembly drawings.

\subsection{TEST AND INSPECTION}

\subsection{General}

All dimensions noted with hexagonal boxes on the reference engineering drawings shall be inspected with calibrated gages and documented in accordance with RRD-JS-24 or with the equivalent Seller's procedures and reporting forms approved by the CTR.

\subsection{Fuel Plates}

The test and inspection requirements for HFIR fuel plates are contained in the following sections.

\subsubsection{Fuel Loading}

The ${ }^{235} \mathrm{U}$ loading in each fuel plate for compliance with the quantity specified in Section 6.2 shall be determined from the weight of constituents dispensed, corrected for the weight loss during compacting (weight of compact), and the chemical and isotopic analysis of the constituents. The correction for weight lost shall be determined and documented based on the quantitative analysis of fuel plates. Semi-quantitative verification of the plate fuel loading in each fuel plate shall be determined by gamma scanning. Verification of the uranium loading may require periodic destructive analysis of randomly selected fuel plates.

Page 17 of 36 
ORNLIRRD/NT-37N3

HFIR-SS-601, HFIR Core Components

RRD.FE-3, Rev. 3

Specification for High Flux Isotope

Reactor Fuel Elements

\subsubsection{Fuel Core Configuration}

As a flat plate, configuration of the fuel core in each fuel plate for compliance with the applicable engineering drawings shall be inspected using either:

(1) a template that will outline the maximum and minimum dimensions of the fuel core when examined under a fluoroscope, or

(2) digital radiography

If the fuel core falls outside the prescribed outlines, the plate shall be radiographed and any nonconformance reported on an SNR in accordance with Section 9.6 of this specification.

To verify the above inspection, a sample from acceptable fuel plates fabricated shall be radiographed and the core dimensions measured. If the core configuration of the sample is found to be in violation, $100 \%$ of the fuel plates in the group shall be radiographed and the fuel core configuration for compliance redetermined from the radiographs.

\subsubsection{Fuel Distribution}

The fuel distribution in each fuel plate shall be quantitatively determined by scanning the entire surface of each plate through a collimated $X$-ray beam that covers a 0.080 -in.-diameter area on the plate and comparing the attenuation of the $X$-ray beam with calibration standards.

Two scanners (one digital and the other analog) for measuring fuel distribution in HFIR fuel plates are provided by the Company for use by the Seller. When funds are available, the analog scanner will be converted to digital operation. In the interim, the analog scanner may be used by the Seller for the acceptance of fuel plates for homogeneity. Fuel plates rejected by the analog scanner shall be rescanned by the Seller on the digital scanner and submitted on an SNR for disposition by the company. The functional requirements of the two scanners are as follows.

1. The calibration standards supplied by the Company are contoured to match the $\mathrm{X}$-ray attenuation of the fuel distributions in ORNL engineering drawings D-42114 and D-42122 and of fuel plates containing the specified $\mathrm{U}_{3} \mathrm{O}_{8}$ fuel particles (RRD-MS-106).

2. The longitudinal scanning of the fuel distribution in each plate shall be done in 0.080 -in.wide track increments across the width of each plate with a 0.020 -in.-Overlap between tracks. The standards shall be scanned on each track.

3. For the digital scanner, data shall be digitized and recorded in 0.060-in. increments along the length of the plate and calibration standards. The digitized data shall be recorded in two tables as follows:

Average. The average data shall be calculated as the arithmetic means of at least seven data inputs acquired during a 0.060 -in. track movement ("LOC" data file).

Maximum spot. The maximum spot data shall be recorded as the maximum fuel density from the data inputs points acquired during each .060-in. track movement "MAX" data file).

Page 18 of 36 
ORNLIRRDINT-37N3

HFIR-SS-601, HFIR Core Components

RRD-FE-3, ReV 3

Specification for High Flux Isotope

Reactor Fuel Elements

4. During scanning of fuel plates on the analog scanner, deviations from the specified homogeneity requirements shall be recorded in a manner that shows the calibration standards and the location of the defect(s) in a fuel plate on paper strip charts.

5. For the digital scanner, an exponentially weighted running average fuel density is used to simulate the operation of the analog scanner's existing $R C$ circuit. It is calculated by the following recursion relation, which gives the exponentially weighted running average at axial point $n, Y(n)$, in terms of the exponentially weighted running average at $n-1, Y(n-1)$, and the averaged fuel density (from the "LOC" data file) at point $n, X(n)$, as follows:

$$
Y(n)=A^{*} Y(n-1)+(1-A)^{*} X(n)
$$

The value of $A=0.91393$ best simulates the operation of the analog scanning equipment when operating at a speed of $300 \mathrm{in} . / \mathrm{min}$.

\subsubsection{Fuel Homogeneity}

1. The fuel distribution shall be determined by measuring the $X$-ray attenuation in the fuel plates compared to the Company supplied calibration standards.

2. The maximum fuel concentration in any 0.080 -in. diameter spot over the entire surface of a fuel core shall not exceed the attenuation of the $+27 \%$ calibration standard for that track's location on the fuel distribution contour.

3. The maximum average density as determined internally by the analog scanner or with the exponentially weighted average function described in Section 8.2.3.5 shall not exceed the attenuation of the $+12 \%$ calibration standards for any integration area along any 0.080 -in.- wide track and that track's location on the fuel distribution contour.

4. Any fuel plate that does not meet the specified requirements in Section 8.2 .4 .2 shall be rejected.

5. Any fuel plate that does not meet the specified requirements in Section 8.2 .4 .3 shall be submitted as a supplier nonconformance request (SNR) per Section 9.6 and shall include details as to the location and magnitude of the deviated condition(s) for disposition by the Company.

6. In lieu of Section 8.2.4.5, the Company can approve a method of disposition at the Seller's facility of any fuel plate that does not meet the specified requirements in Section 8.4.2.3. This method shall be submitted as a supplier deviation request (SDR) per Section 9.6 and shall be approved by the Company.

\subsubsection{Boron Distribution}

The boron distribution across the width of the inner fuel plates (as specified in Section 6.3) shall be verified by the destructive sampling and analysis of one randomly selected plate from the 


\author{
ORNLIRRD/NT $37 / N 3$ \\ HFIR-SS-601, HFIR Core Components \\ RRD FE-3, Rev, 3 \\ Specification for High Flux Isotope \\ Reactor Fuel Elements
}

group of fuel plates selected for each inner fuel element. A rejected plate from a lot of plates contained in the group may be used for this destructive examination.

1. This plate shall be sampled by punching fifteen $1 / 2$-in.-diameter specimens in three rows with equal boron concentration randomly along the length of the plate. One row of holes shall be on or near the fuel hump.

2. Each sample shall be analyzed by a laboratory and methods as appropriate in conformance with ANSI/ANS-8.21, Section 5.3.1.3.

3. The distribution of boron from the sample plates shall be as follows:

- Samples within minimum fuel core outline: $\pm 35 \%$ of calculated value.

- Samples along edges of core outline: $+35-100 \%$ of calculated value.

4. If any sample value falls outside the specified range, three additional plates from the group shall be sampled and analyzed. If any sample value from these three additional plates falls outside the specified range, all the plates from the group shall be rejected.

\title{
8.2.6 Nonbond
}

Fuel plates shall be inspected for presence of any nonbonded areas or blisters by ultrasonic scanning of the entire surface of each fuel plate.

1. The ultrasonic test shall be conducted with sufficient sensitivity to detect a nonbonded area or blister of $<0.063 \pm 0.005$-in. diameter.

2. Within the maximum core outline plus a $1 / 4$-in. margin, any indication $>0.063 \pm 0.005 \mathrm{in}$. shall be cause to reject the plate.

3. Outside the core outline and margin, any indication $>0.125 \pm 0.005 \mathrm{in}$. shall be cause to reject the plate.

4. Calibration standards shall be scanned before and after scanning a group of plates.

\subsubsection{Clad Thickness and Bonding}

The clad thickness and bonding shall be determined by destructive examination of one randomly selected fuel plate from the group selected for each fuel element. A rejected plate from the lot of plates contained in the group may be used for this destructive examination.

1. This plate shall be transversely sectioned in the middle and equidistant from the middle to each end. The end transverse sections shall be further sectioned along their centerline and samples prepared to allow examination from approximately $1 / 2 \mathrm{in}$. beyond the core and extending $1-1 / 2 \mathrm{in}$. into the core.

2. The clad thickness shall be determined by measuring the clad thickness on both sides of the fuel core in each of the prepared sections. The minimum clad thickness shall be $>0.007 \mathrm{in}$. 
ORNL/RRDINT $-37 N 3$

HFIR-SS-601, HFIR Core Components

RRD-FE-3, Rev. 3

Specification for High Flux Isotope

Reactor Fuel Elements

3. Bonding shall be evaluated by metallographic examination of the interfaces in polished and etched sections of all the interfaces. Acceptable bonding is defined as (1) no visible separation between the layers when viewed under $10 \times$ magnification and (2) $\geq 50 \%$ grain growth evenly distributed across the aluminum-to-aluminum interfaces as viewed under polarized light at $50 \mathrm{X}$.

4. If any value falls outside the specified range, three additional plates from the group shall be sampled and analyzed. If any sample value from these three additional plates falls outside the specified range, all the plates from that group shall be rejected.

\subsubsection{Radioactive Surface Contamination}

The radioactive surface contamination shall be determined by smearing the surfaces of flat fuel plates and counting these smears with appropriate radiation measuring equipment. The radioactive surface contamination of a flat fuel plate shall be $<5$ disintegrations per minute (dpm) per $100 \mathrm{~cm}^{2}$ alpha (equivalent to $1 \mu^{235} \mathrm{U}$ per $100 \mathrm{~cm}^{2}$ ). Statistically appropriate sampling of fuel plates may be used to ensure that the radioactive contamination level is maintained below the specified level.

\subsection{Fuel Element Assembly}

The test and inspection requirements for the assembly of HFIR fuel elements are contained in the following section.

\subsubsection{Uranium Loading}

The total loading of ${ }^{235} \mathrm{U}$ in each fuel element shall be determined by the summation of the ${ }^{235} \mathrm{U}$ contents (as determined in Seclion 8.2.1) in each plate contained in the element.

\subsubsection{Boron Loading}

The total loading of ${ }^{10} \mathrm{~B}$ in each inner element shall be based on the summation of dispensed weights of boron carbide contained in each plate and the certified ${ }^{10} \mathrm{~B}$ content in the $\mathrm{B}_{4} \mathrm{C}$ material used.

\subsubsection{Coolant Channel Spacing}

Each coolant channel in each fuel element shall be continuously measured along the entire length of each coolant channel at the following radial locations. Locations are in inches $\pm 1 / 8 \mathrm{in}$. from the centerline of the elements.

\begin{tabular}{cccccc}
\multicolumn{6}{c}{ Gage position number } \\
& 1 & 2 & 3 & 4 & 5 \\
\hline Inner fuel element & 3.10 & 3.56 & 4.05 & 4.40 & 4.80 \\
Outer fuel element & 6.20 & 6.64 & 7.22 & 7.61 & 7.90 \\
\hline
\end{tabular}

The device for measuring the channel spacing shall be furnished by the Company.

Page 21 of 36 
ORNL/RRDINT-37N3

HFIR-SS-601, HFIR Core Components

RRD-FE-3, ReV. 3

Specification for High Flux Isotope

Reactor Fuel Elements

The coolant channel spacing tolerances along the length of the fuel elements are given in Table 8.1.

Table 8.1. Coolant channel spacing tolerances (in.)

\section{A. Inner element}

Axial Region 1: Top 21 inches of channel

\begin{tabular}{|c|c|c|c|c|c|c|}
\hline Gage position number & 1 & 2 & 3 & 4 & 5 & $\begin{array}{l}\text { Row } \\
\text { average }\end{array}$ \\
\hline Local minimum & 0.040 & 0.040 & 0.040 & 0.040 & 0.040 & \\
\hline Local maximum & 0.060 & 0.060 & 0.060 & 0.060 & 0.060 & \\
\hline Station (row) avg. min. & & & & & & 0.044 \\
\hline Station (row) avg. max. & & & & & & 0.056 \\
\hline Track avg. min. & 0.040 & 0.040 & 0.040 & 0.040 & 0.040 & \\
\hline Track avg. $\max$ & 0.060 & 0.060 & 0.060 & 0.060 & 0.060 & \\
\hline \multicolumn{7}{|c|}{ Axial Region 11: Bottom 3 inches of channel } \\
\hline Gage position number & 1 & 2 & 3 & 4 & 5 & $\begin{array}{l}\text { Row } \\
\text { average }\end{array}$ \\
\hline Local minimum & 0.040 & 0.040 & 0.040 & 0.040 & 0.040 & \\
\hline Local maximum & 0.060 & 0.060 & 0.060 & 0.060 & 0.060 & \\
\hline Station (row) avg. min. & & & & & & 0.044 \\
\hline Station (row) avg. max. & & & & & & 0.056 \\
\hline Track avg. min. & 0,040 & 0.040 & 0.040 & 0.040 & 0.040 & \\
\hline Track avg. max. & 0.060 & 0.060 & 0.060 & 0.060 & 0.060 & \\
\hline
\end{tabular}

Overall average of entire length of all channels, all tracks: $\min .0 .049 \mathrm{in}$, max. $0.051 \mathrm{in}$.

\section{B. Outer element}

Axial Region 1: Top 21 inches of channel

\begin{tabular}{|l|l|l|l|l|l|l|}
\hline Gage position number & 1 & 2 & 3 & 4 & 5 & $\begin{array}{l}\text { Row } \\
\text { average }\end{array}$ \\
\hline Local minimum & 0.040 & 0.040 & 0.040 & 0.040 & 0.040 & \\
\hline
\end{tabular}

Page 22 of 36 
ORNL/RRDINT $-37 N 3$

HFIR-SS-601, HFIR Core Components

RRD-FE-3, Rev. 3

Specification for High Flux Isotope

Reactor Fuel Elements

Table 8.1. Coolant channel spacing tolerances (in.)

\begin{tabular}{|c|c|c|c|c|c|c|}
\hline Local maximum & 0.060 & 0.060 & 0.060 & 0.060 & 0.060 & \\
\hline Station (row) avg. min. & & & & & & 0.044 \\
\hline Station (row) avg. max. & & & & & & 0.056 \\
\hline Track avg. min. & 0.040 & 0.040 & 0.040 & 0.040 & 0.040 & \\
\hline Track avg. max. & 0.060 & 0.060 & 0.060 & 0.060 & 0.060 & \\
\hline \multicolumn{7}{|c|}{ Axial Region II: Bottom 3 inches of channel } \\
\hline Gage position number & 1 & 2 & 3 & 4 & 5 & $\begin{array}{l}\text { Row } \\
\text { average }\end{array}$ \\
\hline Local minimum & 0.040 & 0.040 & 0.040 & 0.040 & 0.040 & \\
\hline Local maximum & 0.060 & 0.060 & 0.060 & 0.060 & 0.060 & \\
\hline Station (row) avg. min. & & & & & & 0.044 \\
\hline Station (row) avg. max. & & & & & & 0.056 \\
\hline Track avg. min. & 0.040 & 0.040 & 0.040 & 0.040 & 0.040 & \\
\hline Track avg. max. & 0.060 & 0.060 & 0.060 & 0.060 & 0.060 & \\
\hline
\end{tabular}

Overall average of entire length of all channels, all tracks: min. $0.049 \mathrm{in}$; max. $0.051 \mathrm{in}$.

\subsubsection{Welding}

\section{Fuel Plates}

The quality of the attachment welds for fuel plates cannot be practically examined by nondestructive means and must be controlled by strict adherence to the welding materials requirements, the welding procedures, evaluation of weld test samples before and after the welding of each element, visual inspection of the as-welded weld surfaces, and visual inspection of the finished machined surfaces of the welds.

\section{(a) Weld Test Samples}

(1) Visual examination. The surfaces of the weld bead on the weld test samples shall be free of defects such as cracks, incomplete fusion, or voids. The weld beads shall have a uniform contour and be free of oxidation, and the termination crater(s) shall have a depth less than would be required to provide a smooth surface on a fuel element after final machining.

Page 23 of 36 
ORNLIRRD/NT-37N3

HFIR-SS-601, HFIR Core Components

RRD-FE-3, Rev, 3

Specification for High Flux Isotope

Reactor Fuel Elements

(2) Tensile strength. The pull strength of the attachment of the tensile test plates, with the force applied normally to the bottom surface of the slot, shall be $>100$ pounds.

Metallographic examination. A minimum of $95 \%$ of the dummy weld test plates shall be welded to the side plate across the entire surface of the fuel plate; the other $5 \%$ shall be joined over at least $75 \%$ of the thickness of the fuel plate. The penetration of weld metal into the weld groove shall be $>10 \%$ except for the first $2 \mathrm{in}$. at the weld start. Full penetration of the slide plate slots is not desirable and shall be avoided.

(4) Welding of a fuel element shall not begin until the before-and/or-after (from preceding element) weld test sample meets visual and tensile strength requirements listed in (1) and (2) above.

(5) If the before-and/or-after (from preceding element) weld test sample does not meet the visual and tensile strength requirements listed above, welding of additional test samples shall continue until two consecutive samples meet all the requirements of this specification.

(6) If an after weld sample does not meet the requirements of this section, an SNR shall be submitted to the CTR for disposition.

\section{(b) Visual inspection As-welded}

All as-welded weld beads and adjacent heat-affected surfaces shall be visually inspected. The face side of each weld shall be free of defects such as cracks, incomplete fusion, or voids. The weld beads shall have a uniform contour and be free of oxidation, and the termination crater(s) shall have a depth less than that required to provide a smooth surface on the fuel element after final machining. Any deficiency noted in this inspection shall be repaired and reinspected before final machining.

\section{(c) Visual Inspection after Machining}

After final machining, all weld surfaces shall be visually inspected. Porosity in the GMAW cannot be avoided and is permissible if it does not exceed that specified for radiographic inspection in the ASME Boiler and Pressure Vessel Code, Section VIII, Appendix IV, "Porosity Charts for Plate $1 / 4 \mathrm{in}$. or Less." The amount of large porosity shall be $<1 / 2$ the amount shown in the figure. The presence of cracks or voids extending into the side plate thickness or porosity exceeding those permitted in this section shall be submitted on an SNR. The SNR shall include the proposed weld repair procedure, if applicable.

\section{End Fittings}

(a) Visual inspection as welded. The face side of each weld shall be free of defects such as cracks, incomplete fusion, or voids. The weld beads shall have a uniform contour and be free of oxidation, and the termination crater(s) shall have a depth less than that

Page 24 of 36 
ORNLIRRDIINT-37N3

HFIR-SS-601, HFIR Core Components

RRD-FE-3, ReV. 3

Specification for High Flux Isotope

Reactor Fuel Elements

required to provide a smooth surface on the fuel element after final machining. Any deficiency noted in this inspection shall be repaired and reinspected before final machining.

(b) Radiographic examination. Each end fitting weld shall be inspected by radiography. Welds shall be unacceptable if the radiograph shows any cracks or any of the types of discontinuities as specified in ANSI/AWS D1.2, Sections 9.15.2.1 through 9.15.2.4. If a defect is noted in the radiographic inspection of an end fitting weld, an SNR shall be submitted for disposition.

(c) Visual inspection after machining. After final machining, any reportable weld defects shall be submitted on an SNR. The SNR shall include the proposed weld repair procedure, if applicable.

\subsection{QUALITY ASSURANCE AND DOCUMENTATION}

\subsection{Quality Assurance Plan}

The Seller shall document and maintain quality systems that address Company requirements (10 CFR 830.120). Measurement equipment used for tesis and inspection shall be calibrated in conformance with MIL-C-45662 or Company-approved equal. A description of the quality assurance program and the procedures to maintain adequate control and quality shall be furnished to the Company.

\subsection{Process Control}

The Seller shall establish a process control program whereby checks are made on manufacturing processes, operational procedures, intermediate product characteristics, and equipment to demonstrate that the process stability during production is at least equal to that demonstrated during qualification. The Seller shall develop and implement plan for providing process control through statistical trend analysis of key attributes. The plan, including the list of key attributes and appropriate measures of process stability or yields to be used for comparison, will be submitted to CTR for concurrence.

If process yields fall significantly below historical values over a 3-month period, as defined within the plan, the specific production tasks affecting these yields shall be evaluated by the Seller and this evaluation shall be provided to the CTR in writing. Depending upon the findings and recommendations of this evaluation, the process and/or personnel associated with this task(s) may be disqualified for continued HFIR production.

\subsection{Procedures}

Work activities shall be performed, controlled, and documented in accordance with written procedures approved by the CTR. The operators and inspectors shall be trained to these written procedures for their specific tasks and shall perform their HFIR production tasks in strict accordance with these written procedures. The Seller shall monitor the conformance of the

Page 25 of 36 


\author{
ORNLIRRDINT-37N3 \\ HFIR-SS-601, HFIR Core Components \\ RRD.FE-3, Rev. 3 \\ Specification for High Flux Isolope \\ Reaclor Fuel Elements
}

operators and inspectors to the written procedures and inform the Company of any

nonconformances. The written procedures shall be reviewed at least every 5 years by the Seller to ensure that the procedures are clear. The Seller shall maintain a record of the review and submit all procedures that have been revised for all non-administrative changes.

Administrative changes to procedures do not require the approval of the CTR. Administrative changes shall be defined as (1) clerical changes - e.g., spelling, grammar, punctuation, and typographical errors; (2) restructuring/retyping document without altering the technical contents; (3) additions or changes not relative to manufacturing/inspection/testing procedures - i.e., personnel/ nuclear safety, labor reporting, inventory tracking and production scheduling, security, work center/department number; and (4) verbatim compliance of contract specifications.

\title{
9.4 Requalification
}

Requalification for any fuel plate or fuel element attribute to the requirements of this specification shall be required when the processes, materials, fuel loading, equipment, or personnel, which had been previously qualified, are changed. The Seller shall notify the Company of any proposed process change and then must document on an SDR to the satisfaction of the Company that the change will have no detrimental effect on the product. Engineering evaluation and/or proof tests will be required to justify a major process change. A proposed major process change cannot be used in production until all the qualification requirements specified in this document have been met, documented, and approved by the Company in writing. Minor process changes or refinements shall be submitted on an SDR for approval by the CTR and RRD QA before implementing in production. The CTR and RRD QA will determine what procedure changes constitule major changes. Editorial or wording changes for clarification in procedures are not considered changes as defined in this section.

\subsection{Personnel Qualification}

Personnel performing work activities shall demonstrate technical proficiency and shall be trained in the use of applicable procedures. Personnel performing radiographic and ultrasonic NDE examinations shall be certified to ASNT procedure SNT-TC-1A, and certification documentation shall be available to the Company. Specific qualifications are required for operating personnel performing powder compacting and welding. These requirements are contained in Sections 9.5.1 and 9.5.2. Operating personnel performing pack assembly, hot rolling, and cold rolling shall be qualified to procedures developed by the Seller. Documentation shall be maintained by the Seller that all operating and inspection personnel are qualified to perform their identified tasks.

\subsubsection{Powder Compacting}

Candidate personnel for powder compacting shall be instructed by the Seller's process engineering department in the proper powder handing, die loading, and powder sweeping techniques. For qualification, the candidate operator shall demonstrate a proficiency in satisfactorily making at least 20 out of 24 compacts from each of the two consecutive outer plate lots. A satisfactory compact is one that has passed all visual and dimensional inspection requirements and the fuel distribution has been determined to be acceptable in the finished 


\author{
ORNLIRRD/NT-37N3 \\ HFIR-SS-601, HFIR Core Components \\ RRD-FE-3, Rev. 3 \\ Specification for High Flux Isotope \\ Reactor Fuel Elements
}

rolled plate. Separate qualification on inner compacts is not required. The qualification of a compacting operator shall be based only on defects directly related to the powder compacting operation(s),

\title{
9.5.2 Welding
}

General qualifications. Welding operators who perform machine welds on HFIR fuel elements shall be qualified for the welding of aluminum tubes of the same diameter and thickness of tubes used on HFIR fuel elements with single " $V$ " groove weld preparation in the $1 G$ position (tube horizontal, rotated) using the HFIR welding equipment or other comparable equipment. The qualification shall be based on the satisfactory completion and documentation of the welds in accordance with the general qualification requirements outlined in ANSI/AWS D1,2, Section 4, Part D. Welders who make hand repair welds on HFIR fuel element and welder(s) used in pack assembly shall be qualified for the appropriate weld type in accordance with the general qualification requirements outlined in ANSI/AWS D1.2, Section 4, Part D. If a Seller has welding operators or welders who are currently qualified for welding on HFIR fuel elements under different criteria, these welding operators or welders shall be considered qualified.

Fuel plate welding. In addition to the general personnel qualification requirements, a candidate welding operator for HFIR fuel elements shall demonstrate the successful welding of at least two consecutive weld test samples of each type in accordance with the requirements in Section 8.3.4. A candidate welding operator shall be supervised by a welding engineer or qualified HFIR fuel element welding operator during qualification. The results of this qualification test shall be documented and reviewed with the Seller's process engineer before approval of the candidate welding operator for production welding of HFIR fuel elements. A requalification of a HFIR welding operator shall be required if more than 12 months has elapsed since the operator welded a HFIR element.

End fitting weiding. In addition to the general personnel qualification requirements, a candidate replacement welding operator for end fitting welding shall be supervised by a welding engineer or a qualified HFIR end fitting welding operator for at least two end fitting welds of each type. The results of this qualification shall be documented and reviewed with the Seller's process engineer before approval of the candidate welding operator for production weiding of HFIR fuel elements. A requalification of a HFIR welding operator shall be required if more than 12 months has elapsed since the operator welded a HFIR element.

\subsubsection{Radiography}

The preparation of radiographs shall be performed by ASNT/SNT-TC-1A Certified Level 1 or higher level radiographer. The interpretation of radiographs shall be performed by ASNT/SNT. TC-1A Certified Level II or higher level radiographer.

\subsection{Supplier Deviation and Nonconformance}

The Company shall have the sole authority for determining the acceptability of a proposed deviation or the disposition of a proposed nonconformance. A supplier deviation request (SDR)

Page 27 of 36 
ORNL/RRDINTT-37N3

HFIR-SS-601, HFIR Core Components

RRD-FE-3, Rev. 3

Specification for High Flux Isotope

Reactor Fuel Elements

form and a supplier nonconformance request (SNR) form shall be supplied to the Seller by the Company.

Any proposed deviation from this specification shall be documented on a SDR and approved by the Company before proceeding.

In the event that any component, part, work operation, or fuel element does not meet the specified requirements of this specification and a deviation has not been granted by the Company as identified in the previous paragraph, a SNR may be submitted to the Company for approval. This SNR shall be completed by the Seller up to and including the technical justification of the recommended disposition. A copy of the repair/rework procedure shall be submitted if applicable.

\subsection{Audits and Surveillance}

\subsubsection{Audits and Source Inspection}

The Seller shall permit the Company to conduct pre-award audits and continuing evaluation of his quality system. The Seller shall be subject to source inspection by the Company, both at the Seller's facility and also at subtier suppliers' facilities if deemed necessary. The Company will identify hold points to the Seller to be witnessed by the Company's representative. The Company's source inspection does not constitute final acceptance of a fuel element. The Company may perform physical inspection of the finished fuel element at the Seller's facility prior to shipment. The Company may review all delivery submittals listed in Section 12.6 of this specification prior to the shipment of a finished fuel element, and the Company may also witness the final packaging of fuel elements before shipment.

\subsubsection{Surveillance}

As a part of the Company, Research Reactors Division's Quality Assurance Program source surveillance activities may be conducted at the Seller's facility as deemed necessary by the Company to ensure that quality objectives are met. Such surveillances will include, but not be limited to, auditing and monitoring any work in progress, processes, chemical/physical certifications, final inspection and testing, preparation for shipment, and review of certification data. The Seller shall provide the Company's representative(s) access to all data and operating areas that are pertinent to the contract. Source surveillance by the Company's representative(s) shall not constitute product acceptance by the Company and in no way shall relieve the Seller of the responsibility to furnish acceptable items.

\subsection{Preproduction Qualification}

Before production, the Seller, if not currently qualified, shall demonstrate that the fabrication and inspection techniques used to fabricate both inner and outer fuel elements are capable of conforming to this specification. Before production of reactor-grade fuel plates the results of the preproduction qualifications shall be approved in writing by the Company.

Page 28 of 36 


\author{
ORNU/RRD/NT $-37 / \mathrm{N}$ \\ HFIR-SS-601, HFIR Core Components \\ RRD-FE-3, Rev. 3 \\ Specification for High Flux Isotope \\ Reactor Fuel Elements
}

\title{
9.8.1 Fuel Plate Qualification
}

The fuel plates procedures shall be qualified by satisfactorily producing consecutively in a single operation a minimum of 24 fuel plates for each type of HFIR fuel element in accordance with this specification. These plates shall be identical to the expected production plates.

Flat plates. The Seller will have met the process qualification requirements if at least $80 \%$ of the flat plates of each plate type produced in the qualification run meet the requirements of this specification and the following additional inspections and tests.

Remeasurement of fuel core. After blanking and inspection and before forming, every qualification plate shall be radiographed and the core measured on the radiographic film to show that the core outline and minimum edge conform with the drawing specifications.

Clad thickness and bonding. Three flat plates from the qualification batch for each element type shall be destructively examined for clad thickness and bonding. These plates shall be transversely sectioned in the middle and equidistant from the middle to each end. The end transverse sections shall be further sectioned along their centerline and samples prepared to allow examination from approximately $2 \mathrm{in}$, beyond the core and extending $12 \mathrm{in}$. into the core. Each of these sections shall be examined for conformance to the requirements of Section 8.2.7 of this specification.

Boron content and distribution. The boron loading in inner fuel elements shall be verified by the Seller to demonstrate his ability to control the boron content in fuel plates. Evidence of this control shall be by analysis of three randomly selected fuel plates for total boron content. Each plate shall be dissolved and analyzed by a laboratory and methods as appropriate (ANSI/ANS8.21, Section 5.3.1.3). The total ${ }^{10} \mathrm{~B}$ content determined shall be within the range as specified in Section $6.3\left(0.0164 \pm 0.0016^{10} \mathrm{~B}\right)$.

The boron distribution across the width of each inner fuel plate shall be verified by destructive sampling and analysis of three randomly selected plate from the inner fuel plate qualification lot. The sample analysis shall be as prescribed in Section 8.2 .5 of this specification.

Retesting. If any of the accepted qualification test plates fails any one of the additional destructive test and inspection requirements for preproduction qualification, another lot of plates shall be produced and tested. in addition, twice the number of plates shall be examined for the attribute that failed in the first test to meet the preproduction qualification requirements.

Homogeneity scanner. The precision and accuracy of the digital homogeneity scanner shall be determined during preproduction inspection of fuel plates by the scanning of a special test plate to be supplied by the Company at least three times and statistically analyzing the data. The variance of this data shall be within agreed limits to be established by the Company.

Surface contamination. The fabrication processes involving in handling of fuel powders, the pressing and handling of fuel compacts and pack assembly shall be contained to the extent necessary to consistently fabricale fuel plates with a surface contamination of $<5 \mathrm{dpm}$ per $100 \mathrm{~cm}^{2}$ alpha. During startup the Seller shall demonstrate that the process can consistently 
ORNLIRRD/NT $-37 / N 3$

HFIR-SS-601, HFIR Core Components

RRD-FE-3, Rev. 3

Specification for High Flux Isotope

Reactor Fuel Elements

produce flat plates with a surface contamination below the level specified by smearing all fuel plates produced in the first 5 production lots of fuel plates of each type.

\subsubsection{Fuel Elements}

Prior to the beginning of production operations, draft welding procedure specifications (WPS) for the welding of the fuel plates and end fittings shall be prepared and documented in accordance with the general requirements outlined in ANSI/AWS D1.2, Section 4, Part C, or another procedure specification if approved by the Company.

During preproduction operations, the Seller shall demonstrate that the channel spacing is not altered during subsequent welding of the end fittings and the final machining operations.

\section{Dummy Fuel Elements}

1. To qualify the fabrication process for HFIR fuel assemblies, a minimum of one inner and one outer dummy fuel element shall be fabricated and shipped to the Company for approval.

2. These elements shall be made to the identical engineering drawings and fabrication, test, and inspection procedures planned for producing HFIR fuel elements by the Seller in compliance with this specification except for the fuel plates.

3. The simulated fuel plates in these dummy fuel elements shall be dimensionally identical to those specified for the actual fuel elements except that they shall be made of 6061-0 aluminum sheet stock. The dummy shall be conspicuously marked as such.

4. The Seller shall certify the conformance of these dummy fuel elements to this specification.

\section{Destructive Examination-Fuel Plate Welds}

1. A single dummy fuel element (either inner or outer element) shall be assembled as described Section 9.8 .2 (dummy fuel element) for destructive examination.

2. A minimum of four complete circumferential welds on both the inner and outer side plates shall be welded as specified in Section 7.4 .2 by each welding operator for preproduction qualification.

3. These welds shall meet all the requirements of Section 8.3.4.

4. As welded, the element diameter and plate spacing shall meet the requirements of Sections 8.1 and 8.3 .3 .

5. One inner and one outer weld shall be sectioned along the centerline of the weld and prepared for examination as described for weld test samples. 
ORNL/RRDINT-37N3

HFIR-SS-601, HFIR Core Components

RRD-FE-3, Rev. 3

Specification for High Flux Isotope

Reactor Fuel Elements

6. The sectioned welds shall meet the requirements of the weld test samples, Section 8.3.4.

7. If any weld fails to meet the requirements previously described, a complete weld requalification shall be required.

8. The successful completion of the weld preproduction requirements shall constitute the qualification of the welding procedure specification and the production welding operator(s).

\section{Destructive Examination-End Fitting Welds}

1. One end fitting on a dummy inner and outer element shall be welded as specified in Section 7.4 .3 for destructive examination.

2. These welds shall meet all the requirements of Section 8.3.4.

3. Each weld shall be sectioned and examined.

4. The sections shall be crack free and show a full penetration weld with defects such as slag inclusions and porosity no larger than as specified for radiographic acceptance of the weld.

5. If any weld fails to meet the requirements previously described, a complete weld requalification shall be required.

6. The successful completion of the weld preproduction requirements shall constitute the qualification of the welding procedure specification and the production welding operator.

\section{Qualification Elements}

One complete inner fuel element and one outer fuel element certified to meet the requirements of this specification shall be furnished the Company for approval before full production operation.

\subsection{CLEANLINESS}

\subsection{General}

The aluminum used for fuel cladding in the HFIR fuel elements is subject to pitting corrosion from the presence of many foreign materials that may be left on the aluminum surfaces during fabrication. Also, the completed fuel elements will be operated in a high-purity water environment. To protect the completed fuel plates and elements from pitting corrosion, and to avoid the introduction of ionic and foreign materials into the HFIR water systems, the Seller shall not use any process or material (including packaging or shipping materials) that has the possibility of leaving a residue of certain detrimental materials on the surface of any fuel plate after the final fuel plate cleaning step and after the final cleaning of the completed fuel element. 
ORNLIRRD/NT-37N3

HFIR-SS-601, HFIR Core Components

RRD FE-3, ReV. 3

Specification for High Flux Isolope

Reactor Fuel Elements

The detrimental materials are chlorine, fluorine, copper, lead, nickel, silver, thorium, tin and carbon. If the Seller's processes, whether inadvertent or not, cause any of these detrimental materials to contact the surface of a component, the Seller shall establish cleaning and inspection procedures subject to approval by the CTR for cleaning and maintaining the cleanliness of all fuel plates and completed fuel elements to comply with this requirement. Because trace amounts of these materials are found in cleaning fluids such as alcohol and water, the procedures shall identify the specifications for all cleaning fluids or identify acceptable levels of these impurities that shall be verified through testing of the purchased lot.

Mercury in any form can cause catastrophic corrosion of aluminum and shall be specifically precluded in the procurement of aluminum raw materials and in all processing and manufacturing operations used by the Seller for HFIR fuel elements.

\subsection{Fuel Plates}

1. The use of any abrasive or any procedure that removes $>0.001 \mathrm{in}$. from a surface of a fuel plate shall not be used. A fine aluminum wool or "Scotch Bright" containing fine aluminum oxide as the abrasive may be used to remove surface defects $<0.001 \mathrm{in}$.

2. The Seller shall establish and demonstrate that the production process flow and isolation of radioactive contamination consistently produces flat fuel plates with radioactive surface contamination of $<5 \mathrm{dpm}$ per $100 \mathrm{~cm}^{2}$ alpha.

\subsection{Fuel Elements}

1. The interior and exterior surfaces of the fuel elements and fuel channels shall be free of weld splatter, slag, dirt, oil, scale, paint, marking ink, or any other foreign materials.

2. Pickling or similar cleaning in any stage of fabrication of an assembled fuel element shall not be permitted.

\subsection{PACKAGING AND SHIPPING}

1. Before shipping, each fuel element shall be individually wrapped in green colored polyethylene plastic wrap or bag (0.004 in. minimum thickness) to protect the element from dust and moisture. Clear plastic wrap is not allowed in the Company's reactor building.

2. The Seller shall load each completed fuel element into an individual shipping container supplied by the Company.

3. After loading, each shipping container shall be provided with a tamper-proof seal as required for the shipment of special nuclear materials.

Page 32 of 36 
ORNLIRRDINT-37N3

HFIR-SS-601, HFIR Core Components

RRD-FE-3, Rev. 3

Specification for High Flux Isotope

Reactor Fuel Elements

4. The Company will be responsible for shipping the fuel elements from the Seller's facilities to the Company's facilities in Oak Ridge, Tennessee.

\subsection{RECORDS, SAMPLES, AND INFORMATION TO BE SUPPLIED}

The Seller shall perform regular statistical trend analysis for process control and provide the data to the CTR semi-annually.

\subsection{Engineering Drawings and Material Specifications}

The Company will maintain all reference drawings and material specifications referenced in this specification. All other engineering drawings and process materials specifications shall be maintained by the Seller. A copy of all proposed changes to an approved drawing or specification shall be submitted on a deviation request form for Company approval and incorporation into an engineering drawing or specification. The Seller is encouraged to use the applicable revision of the reference engineering drawings for working drawings. If the Seller elected to produce and use working drawing comparable to the referenced engineering drawings for use on the shop floor these working drawings and their revisions shall be approved by the Company for configuration control.

\subsection{Procedures}

A copy of procedures and route cards approved by the Seller for use in fuel element fabrication shall be submitted to the Company for approval. These shall include procedures for fuel plate fabrication, fuel element fabrication, inspection and testing, cleanliness, packaging and shipping, quality assurance, and preproduction qualification. All copies of approved procedures and route cards used in production shall be numbered and controlled. Any proposed modification of an approved procedure or route card shall be submitted on a deviation request for approval by the Company.

\subsection{Production Records}

Production records including route cards, quality deficiency notices, temperature strip charts, radiographs, inspection data, and materials inspection and identification data that are not included in certification packages shall be retained by the Seller until the HFIR element(s) related to this information is used in the HFIR. The Company will inform the Seller when a specific fuel element has been used in the HFIR. Alternatively, if the Seller is not notified that the HFIR element has been used in the HFIR within two years after delivery of the HFIR element, the Seller may ship the production records to the Company at its discretion.

\subsection{Safety-Related Materials Certification and Archive Samples}

1. For each lot of material, certified copies of the test and inspection results shall be retained by the Seller along with certifications that the materials comply with the requirements of this specification until the HFIR element(s) related to this information is used in the HFIR.

Page 33 of 36 
ORNLIRRDINT $-37 / 13$

HFIR-SS-601, HFIR Core Components

RRD-FE-3, ReV. 3

Specification for High Flux Isotope

Reactor Fuel Elements

2. One properly identified archive sample from each material lot of (1) uranium oxide, (2) boron carbide, (3) aluminum powder, (4) aluminum weld rod or wire, (5) aluminum plate and sheet, and (6) aluminum tubing shall be retained by the Seller until the HFIR elements containing the materials are used in the HFIR.

3. The Company will inform the Seller when a specific fuel element has been used in the HFIR.

4. Alternatively, if the Seller is not notified that the HFIR element has been used in the HFIR within two years after delivery of the HFIR element, the Seller may ship the SafelyRelated Materials Certifications and Archive Samples to the Company at its discretion.

\subsection{Preproduction Procedure Qualification Results}

A copy of all preproduction qualification test results and a certification that the preproduction qualification tests have met the requirements of this specification shall be furnished to the Company. The Seller does not need to meet this requirement if the contract is a continuation of HFIR element work from a previous contract. These tests results, if required to be submitted, shall include the following:

1. Fuel plates. Prequalification test data to be furnished for both inner and outer type fuel plates shall include visual, dimensional, radiographic, destruclive, and uranium homogeneity and boron distribution and content.

2. Fuel elements. Prequalification test data to be furnished for both inner and outer fuel elements shall include, visual, dimensional, channel spacing, welding qualfication, and welding test and inspection results.

\subsection{Data Furnished with Each Element}

A certification package for each fuel element shall be supplied to the Company before shipment of the element. The certification package shall contain the following information:

1. A certification that the fuel element complies with the requirements of this specification.

2. Identification number of the fuel element,

3. Lot number and weight of total uranium and ${ }^{235} \mathrm{U}$ in each fuel plate and total in fuel element.

4. Lot number and weight of boron carbide in each inner element.

5. Measured values of dimensions indicated on the assembly drawing for each fuel element.

6. Fuel plate weld test samples and inspection report.

Page 34 of 36 


\section{ORNL/RRDINT $-37 N 3$ \\ HFIR.SS-601, HFIR Core Components \\ RRD FE-3, Rev. 3 \\ Specification for High Flux Isotope \\ Reactor Fuel Elements}

7. Radiographic analysis report of end-fitting welds.

8. Destructive examination inspection report on bond quality and clad thickness.

9. Analytical report from destructive examination for boron content from fuel plate samples.

10. Identification of all welding machine operators and welders.

11. A listing of all SNRs and deviation requests issued and approved for any component or process affecting this element.

12. A report indicating that the following inspections have been made, and by whom, and summarizing the results:

(1) fuel plate dimensions ( for control fuel plates only)

(2) fuel channel spacing data

(3) side plate thickness 
ORNL/RRD/INT-37N3

HFIR-SS-601, HFIR Core Components

RRD-FE-3, Rev. 3

Specification for High Flux Isotope

Reactor Fuel Elements

\section{Appendix A}

Cross Reference to BWXT Working Drawings (July 2004)

\begin{tabular}{|l|c|c|c|c|c|c|}
\hline ASSEMBLY DRAWINGS & ORNL & Rev. & Date & BWXT/TI & Rev. & Date \\
\hline HFIR inner fuel element-assembly & E-42118 & Q & Jul-98 & DG-8-7213 & U & Mar-96 \\
\hline HFIR outer fuel element_assembly & E-42126 & M & Jul-98 & DG-8-7214 & X & Mar-96 \\
\hline ComponENT DETAILs & & & & & \\
\hline HFIR inner fuel element-fuel plate loading details & D-42114 & H & Apr-91 & DG-8-7146 & T & Feb-94 \\
\hline HFIR outer fuel element-fuel plate loading details & D-42122 & H & Apr-91 & DG-8-7148 & S & Feb-94 \\
\hline $\begin{array}{l}\text { HFIR inner fuel element fuel plate-true involute } \\
\text { Curvature design details }\end{array}$ & D-42113 & G & Apr-91 & DG-8-7147 & F & Oct-68 \\
\hline $\begin{array}{l}\text { HFIR outer fuel element fuel plate-true involute } \\
\text { Curvature design details }\end{array}$ & D-42121 & H & Apr-91 & DG-8-7149 & F & Oct-68 \\
\hline HFIR inner fuel element-inner side plate \#1 & D-42112 & H & Apr-91 & DG-8-7218 & $\mathrm{J}$ & Aug-75 \\
\hline HFIR inner fuel element-outer side plate \#2 & D-42117 & H & Apr-91 & DG-8-7217 & J & Aug-75 \\
\hline HFIR outer fuel element-inner side plate \#3 & D-42120 & H & Apr-91 & DG-8-7216 & M & Aug-75 \\
\hline HFIR outer fuel element-outer side plate \#4 & D-42125 & J & Apr-91 & DG-8-7215 & M & Aug-75 \\
\hline
\end{tabular}

Page 36 of 36 


\section{APPENDIX C}

BOISE STATE TECENTER TECHNOLOGY COMMERCIALIZATION MODEL 
PHASES, STAGES, \& STEPS

\begin{tabular}{|c|c|c|c|}
\hline & TECHNICAL & MARKET & BUSINESS \\
\hline \multicolumn{4}{|c|}{ CONCEPT PHASE } \\
\hline $\begin{array}{l}\text { Stage } 1 \\
\text { Investigation }\end{array}$ & $\begin{array}{c}\text { TECHNICAL ANALYSIS } \\
\text { STEP } 1\end{array}$ & $\begin{array}{c}\text { MARKET NEEDS } \\
\text { ASSESSMENT } \\
\text { STEP } 2\end{array}$ & $\begin{array}{c}\text { VENTURE ASSESSMENT } \\
\text { STEP } 3\end{array}$ \\
\hline \multicolumn{4}{|c|}{ DEVELOPMENT PHASE } \\
\hline $\begin{array}{l}\text { Stage } 2 \\
\text { Feasibility }\end{array}$ & $\begin{array}{l}\text { TECHNICAL FEASIBILITY } \\
\text { STEP } 4\end{array}$ & $\begin{array}{l}\text { MARKET STUDY } \\
\text { STEP } 5\end{array}$ & $\begin{array}{l}\text { ECONOMIC FEASIBILITY } \\
\text { STEP } 6\end{array}$ \\
\hline $\begin{array}{l}\text { Stage } 3 \\
\text { Development }\end{array}$ & $\begin{array}{c}\text { ENGINEERING PROTOTYPE } \\
\text { STEP } 7\end{array}$ & $\begin{array}{c}\text { STRATEGIC MARKET PLAN } \\
\text { STEP } 8\end{array}$ & $\begin{array}{c}\text { STRATEGIC BUSINESS PLAN } \\
\text { STEP } 9\end{array}$ \\
\hline $\begin{array}{l}\text { Stage } 4 \\
\text { Introduction }\end{array}$ & $\begin{array}{l}\text { PRE-PRODUCTION PROTOTYPE } \\
\text { STEP } 10\end{array}$ & $\begin{array}{l}\text { MARKET VALIDATION } \\
\text { STEP } 11\end{array}$ & $\begin{array}{l}\text { BUSINESS START-UP } \\
\text { STEP } 12\end{array}$ \\
\hline & COMN & CIAL PHASE & \\
\hline
\end{tabular}




\begin{tabular}{|l|c|c|c|}
\hline Stage 5 & PRODUCTION & SALES AND DISTRIBUTION & BUSINESS GROWTH \\
Growth & STEP 13 & STEP 14 & STEP 15 \\
\hline Stage 6 & PRODUCTION SUPPORT & MARKET DIVERSIFICATION & BUSINESS MATURITY \\
Maturity & STEP 16 & STEP 17 & STEP 18 \\
\hline
\end{tabular}

\section{THE TECHNOLOGY COMMERCIALIZATION MODEL}

\section{KEY QUESTIONS}

\begin{tabular}{|c|c|c|c|}
\hline & TECHNICAL & MARKET & BUSINESS \\
\hline \multicolumn{4}{|c|}{ CONCEPT PHASE } \\
\hline Stage 1 & $\begin{array}{l}\text { TECHNICAL ANALYSIS } \\
\text { STEP } 1\end{array}$ & $\begin{array}{l}\text { MARKET NEEDS ASSESSMENT } \\
\text { STEP } 2\end{array}$ & $\begin{array}{l}\text { VENTURE ASSESSMENT } \\
\text { STEP } 3\end{array}$ \\
\hline Investigation & $\begin{array}{l}\text { Is this product new, unique, and } \\
\text { technically feasible? }\end{array}$ & $\begin{array}{l}\text { Does this product meet a clear } \\
\text { market demand or solve a } \\
\text { problem? }\end{array}$ & $\begin{array}{l}\text { Will this product or venture } \\
\text { opportunity make a profit? }\end{array}$ \\
\hline \multicolumn{4}{|c|}{ DEVELOPMENT PHASE } \\
\hline Stage 2 & $\begin{array}{l}\text { TECHNICAL FEASIBILITY } \\
\text { STEP } 4\end{array}$ & $\begin{array}{l}\text { MARKET STUDY } \\
\text { STEP } 5\end{array}$ & $\begin{array}{l}\text { ECONOMIC FEASIBILITY } \\
\text { STEP } 6\end{array}$ \\
\hline Feasibility & $\begin{array}{l}\text { What are the total costs associated } \\
\text { with producing the product? }\end{array}$ & $\begin{array}{l}\text { Who will buy the product, how } \\
\text { many will be bought and at what } \\
\text { price? }\end{array}$ & $\begin{array}{l}\text { Does this opportunity generate } \\
\text { sufficient returns to justify } \\
\text { investment? }\end{array}$ \\
\hline Stage 3 & $\begin{array}{c}\text { ENGINEERING PROTOTYPE } \\
\text { STEP } 7\end{array}$ & $\begin{array}{l}\text { STRATEGIC MARKET PLAN } \\
\text { STEP } 8\end{array}$ & $\begin{array}{l}\text { STRATEGIC BUSINESS PLAN } \\
\text { STEP } 9\end{array}$ \\
\hline Development & $\begin{array}{l}\text { Do you have a prototype that exactly } \\
\text { represents the product? }\end{array}$ & $\begin{array}{l}\text { Have you profiled and finalized } \\
\text { the target market? }\end{array}$ & $\begin{array}{l}\text { Have you finalized your business } \\
\text { model, identified total financial } \\
\text { needs, and secured seed capital? }\end{array}$ \\
\hline Stage 4 & $\begin{array}{c}\text { PRE-PRODUCTION PROTOTYPE } \\
\text { STEP } 10\end{array}$ & $\begin{array}{l}\text { MARKET VALIDATION } \\
\text { STEP } 11\end{array}$ & $\begin{array}{l}\text { BUSINESS START-UP } \\
\text { STEP } 12\end{array}$ \\
\hline Introduction & $\begin{array}{l}\text { Have you completed a limited } \\
\text { production and tested for performance } \\
\text { and reliability? }\end{array}$ & Have you made sales? & $\begin{array}{l}\text { Is the management team } \\
\text { operational? }\end{array}$ \\
\hline \multicolumn{4}{|c|}{ COMMERCIAL PHASE } \\
\hline
\end{tabular}


ORNL/TM-2010/241

\begin{tabular}{|c|c|c|c|}
\hline $\begin{array}{l}\text { Stage } 5 \\
\text { Growth }\end{array}$ & $\begin{array}{c}\text { PRODUCTION } \\
\text { STEP 13 } \\
\text { Is production process dependable, } \\
\text { reliable and optimized? }\end{array}$ & $\begin{array}{c}\text { SALES AND DISTRIBUTION } \\
\text { STEP } 14 \\
\text { Are you growing market share? }\end{array}$ & $\begin{array}{c}\text { BUSINESS GROWTH } \\
\text { STEP 15 } \\
\text { Are you on course to achieve your } \\
\text { business plan objectives? }\end{array}$ \\
\hline $\begin{array}{l}\text { Stage } 6 \\
\text { Maturity }\end{array}$ & $\begin{array}{c}\text { PRODUCTION SUPPORT } \\
\text { STEP } 16 \\
\text { Are you supporting the product? }\end{array}$ & $\begin{array}{l}\text { MARKET DIVERSIFICATION } \\
\text { STEP } \\
\text { Have you identified your next } \\
\text { generation of products? }\end{array}$ & $\begin{array}{c}\text { BUSINESS MATURITY } \\
\text { STEP 18 } \\
\text { Are you generating and/or } \\
\text { maximizing a return on investment? }\end{array}$ \\
\hline
\end{tabular}

\section{Activities}

\begin{tabular}{|c|c|c|c|}
\hline \multicolumn{4}{|c|}{ CONCEPT PHASE } \\
\hline $\begin{array}{l}\text { Stage } 1 \\
\text { Investigation }\end{array}$ & $\begin{array}{l}\text { TECHNICAL ANALYSIS } \\
\text { STEP 1 } \\
\text { - Define concept } \\
\text { - Confirm critical assumptions } \\
\text { - Survey state of the art } \\
\text { - Id critical barriers } \\
\text { - Evaluate applicability } \\
\text { - Determine technology }\end{array}$ & $\begin{array}{l}\text { MARKET NEEDS ASSESSMENT } \\
\quad \text { STEP } 2 \\
\text { - Conduct market overview } \\
\text { - Id pricing structure } \\
\text { - Id market barriers } \\
\text { - Id risks } \\
\text { - Id distribution channels } \\
\text { - Id trends and competitors }\end{array}$ & $\begin{array}{l}\text { VENTURE ASSESSMENT } \\
\text { STEP } 3 \\
\text { - Estimate profit potential } \\
\text { - Conduct self, enterprise } \\
\text { and commercialization } \\
\text { assessments } \\
\text { - Id professional needs } \\
\text { - Id capital needs }\end{array}$ \\
\hline \multicolumn{4}{|c|}{ DEVELOPMENT PHASE } \\
\hline $\begin{array}{l}\text { Stage } 2 \\
\text { Feasibility }\end{array}$ & $\begin{array}{l}\quad \text { TECHNICAL FEASIBILITY } \\
\text { STEP } 4 \\
\text { - Develop working model } \\
\text { - Test technical features } \\
\text { - Assess preliminary producibility } \\
\text { - Conduct manufacturing } \\
\text { assessment } \\
\text { - Assess safety \& environmental } \\
\text { features } \\
\text { - Finalize designs }\end{array}$ & $\begin{array}{l}\quad \text { MARKET STUDY } \\
\quad \text { STEP } \mathbf{5} \\
\text { - Id and quantify: } \\
\text { - Market size } \\
\text { - Customers } \\
\text { - Volume } \\
\text { - Prices } \\
\text { - Distribution } \\
\text { - Competitors }\end{array}$ & $\begin{array}{l}\text { ECONOMIC FEASIBILITY } \\
\text { STEP } 6 \\
\text { - Formulate financial } \\
\text { assumptions } \\
\text { - Develop pro forma } \\
\text { - Id seed capital } \\
\text { - Form advisory team }\end{array}$ \\
\hline $\begin{array}{l}\text { Stage } 3 \\
\text { Development }\end{array}$ & $\begin{array}{l}\text { ENGINEERING PROTOTYPE } \\
\text { STEP } 7 \\
\text { - Develop prototype } \\
\text { - Id materials and processes } \\
\text { - Conduct tests } \\
\text { - Develop manufacturing methods }\end{array}$ & $\begin{array}{l}\text { STRATEGIC MARKET PLAN } \\
\text { STEP } \mathbf{8} \\
\text { - Id marketing team } \\
\text { - Define target market } \\
\text { - Select market channels } \\
\text { - Field test }\end{array}$ & $\begin{aligned} & \text { STRATEGIC BUSINESS PLAN } \\
& \text { STEP } 9 \\
& \text { - } \\
& \text { - } \text { Decide venture or license } \\
& \text { - } \text { Id manalize intellectual property } \\
& \text { - Select organization structure } \\
& \text { - Write business plan }\end{aligned}$ \\
\hline $\begin{array}{l}\text { Stage } 4 \\
\text { Introduction }\end{array}$ & $\begin{array}{l}\text { PRE-PRODUCTION PROTOTYPE } \\
\text { STEP } 10 \\
\text { - Develop production prototype } \\
\text { - Determine production process } \\
\text { - Select manufacturing equipment } \\
\text { - Design field support system } \\
\text { - Demo product features }\end{array}$ & $\begin{array}{l}\text { MARKET VALIDATION } \\
\text { STEP } \mathbf{1 1} \\
\text { - Establish market } \\
\text { relationships } \\
\text { - Conduct limited sales } \\
\text { - Analyze sales } \\
\text { - Survey customers } \\
\text { - Refine marketing plan } \\
\end{array}$ & $\begin{array}{l}\quad \text { BUSINESS START-UP } \\
\text { STEP } 12 \\
\text { - Establish business function } \\
\text { - Hire staff } \\
\text { - Execute contracts } \\
\text { - Secure first-stage financing }\end{array}$ \\
\hline \multicolumn{4}{|c|}{ COMMERCIAL PHASE } \\
\hline
\end{tabular}


ORNL/TM-2010/241

\begin{tabular}{|c|c|c|c|}
\hline $\begin{array}{l}\text { Stage } 5 \\
\text { Growth }\end{array}$ & \begin{tabular}{|l|}
\multicolumn{1}{c|}{ PRODUCTION } \\
STEP 13 \\
- Prepare commercial design \\
- Establish quality control \\
- Construct facilities \\
- Conduct full production \\
- Finalize internal distribution system
\end{tabular} & $\begin{array}{l}\text { SALES AND DISTRIBUTION } \\
\text { STEP } 14 \\
\text { - Expand distribution } \\
\text { - Analyze competitor } \\
\text { response } \\
\text { - Assess customer satisfaction } \\
\text { - Assess distributorsatisfaction } \\
\text { Refine product features } \\
\end{array}$ & $\begin{array}{l}\text { BUSINESS GROWTH } \\
\text { STEP 15 } \\
\text { - Monitor enterprise position } \\
\text { - Hire and train personnel } \\
\text { - Execute contracts } \\
\text { - Arrange financing } \\
\text { - Institute vision, mission } \\
\text { and management policies } \\
\end{array}$ \\
\hline $\begin{array}{l}\text { Stage } 6 \\
\text { Maturity }\end{array}$ & $\begin{array}{l}\text { PRODUCTION SUPPORT } \\
\text { STEP 16 } \\
\text { - Maximize production } \\
\text { - Establish after market support, } \\
\text { repairs and spares } \\
\text { - Warrantee service } \\
\text { - Implement training program }\end{array}$ & $\begin{array}{l}\text { MARKET DIVERSIFICATION } \\
\text { STEP 17 } \\
\\
\text { - Develop market retention } \\
\text { - Establish market scan } \\
\text { - Id new markets } \\
\text { - Id new products }\end{array}$ & $\begin{array}{l}\text { BUSINESS MATURITY } \\
\text { STEP } 18 \\
\text { - Establish SWOT process } \\
\text { - Invest profits } \\
\text { - Monitor product life cycle } \\
\text { - Monitor business trends } \\
\text { - Monitor mgmt. technologies } \\
\text { - Implement innovations } \\
\end{array}$ \\
\hline
\end{tabular}




\section{DELIVERABLES}

\begin{tabular}{|c|c|c|c|}
\hline & TECHNICAL & MARKET & BUSINESS \\
\hline \multicolumn{4}{|c|}{ CONCEPT PHASE } \\
\hline $\begin{array}{l}\text { Stage } 1 \\
\text { Investigation }\end{array}$ & $\begin{array}{c}\text { TECHNICAL ANALYSIS } \\
\text { STEP } 1 \\
\text { Provisional patent, patent, copyright, } \\
\text { patent scan, license agreement }\end{array}$ & $\begin{array}{l}\text { MARKET NEEDS ASSESSMENT } \\
\text { STEP } 2 \\
\text { Background research materials }\end{array}$ & $\begin{array}{l}\text { VENTURE ASSESSMENT } \\
\text { STEP } 3 \\
\text { Preliminary cost and revenue } \\
\text { estimate }\end{array}$ \\
\hline \multicolumn{4}{|c|}{ DEVELOPMENT PHASE } \\
\hline $\begin{array}{l}\text { Stage } 2 \\
\text { Feasibility }\end{array}$ & $\begin{array}{l}\text { TECHNICAL FEASIBILITY } \\
\text { STEP } 4 \\
\text { A working model of the product }\end{array}$ & $\begin{array}{c}\text { MARKET STUDY } \\
\text { STEP } 5 \\
\text { Primary market research }\end{array}$ & $\begin{array}{l}\text { ECONOMIC FEASIBILITY } \\
\text { STEP } 6 \\
\text { A financial model accurately } \\
\text { representing the business } \\
\text { opportunity }\end{array}$ \\
\hline $\begin{array}{l}\text { Stage } 3 \\
\text { Development }\end{array}$ & $\begin{array}{c}\text { ENGINEERING PROTOTYPE } \\
\text { STEP } 7 \\
\text { An accurate prototype representing the } \\
\text { materials and functionality of the end } \\
\text { product }\end{array}$ & $\begin{array}{l}\text { STRATEGIC MARKET PLAN } \\
\text { STEP } 8 \\
\text { The final marketing plan based } \\
\text { upon discussions with } \\
\text { suppliers, market } \\
\text { representatives, and customers }\end{array}$ & $\begin{array}{c}\text { STRATEGIC BUSINESS PLAN } \\
\text { STEP } 9 \\
\text { The business plan }\end{array}$ \\
\hline $\begin{array}{l}\text { Stage } 4 \\
\text { Introduction }\end{array}$ & $\begin{array}{c}\text { PRE-PRODUCTION PROTOTYPE } \\
\text { STEP } 10 \\
\text { A limited production }\end{array}$ & $\begin{array}{c}\text { MARKET VALIDATION } \\
\text { STEP } 11 \\
\text { Sales }\end{array}$ & $\begin{array}{l}\text { BUSINESS START-UP } \\
\text { STEP } 12 \\
\text { An Enterprise }\end{array}$ \\
\hline \multicolumn{4}{|c|}{ COMMERCIAL PHASE } \\
\hline $\begin{array}{l}\text { Stage } 5 \\
\text { Growth }\end{array}$ & $\begin{array}{l}\text { PRODUCTION } \\
\text { STEP } 13 \\
\text { Production }\end{array}$ & $\begin{array}{c}\text { SALES AND DISTRIBUTION } \\
\text { STEP } 14 \\
\text { Growing sales }\end{array}$ & $\begin{array}{l}\text { BUSINESS GROWTH } \\
\text { STEP } 15 \\
\text { Increasing revenues }\end{array}$ \\
\hline $\begin{array}{l}\text { Stage } 6 \\
\text { Maturity }\end{array}$ & $\begin{array}{l}\text { PRODUCTION SUPPORT } \\
\text { STEP } 16 \\
\text { Maximum production }\end{array}$ & $\begin{array}{l}\text { MARKET DIVERSIFICATION } \\
\text { STEP } 17 \\
\text { New products }\end{array}$ & $\begin{array}{c}\text { BUSINESS MATURITY } \\
\text { STEP } 18 \\
\text { Profits }\end{array}$ \\
\hline
\end{tabular}




\section{INTERNAL DISTRIBUTION}

1. K. J. Beierschmitt (beierschmitt@ornl.gov)

2. C. A. Blue (blueca@ornl.gov)

3. S. E. Burnette (burnettese@ornl.gov)

4. D. H. Cook (dhc@ornl.gov )

5. B. S. Cowell (cowellbs@ornl.gov)

6. R. A. Crone (cronera@ornl.gov)

7. J. H. Miller (millerjh2@ornl.gov)

8. C. V. Parks (parkscv@ornl.gov)

9-10. R. T. Primm III (primmrtiii@ornl.gov)

11. L. D. Proctor (proctorld@ornl.gov)
12. D. G. Renfro (renfrodg@ornl.gov)

13. D. L. Pinkston (pinkstondl@ornl.gov)

14. L. J. Satkowiak (satkowiaklj@ornl.gov)

15. J. D. Sease (seasejd@ornl.gov)

16. K. A. Smith (smithka@ornl.gov)

17. R. L. Snipes (snipesrl@ornl.gov)

18. W. J. Toth (tothwj@ornl.gov)

19. S. J. Zinkle (zinklesj@ornl.gov)

20. ORNL Laboratory Records (hamrindr@ornl.gov)

\section{EXTERNAL DISTRIBUTION}

21. A. Adams, U.S. Nuclear Regulatory Commission, One White Flint North, 11555 Rockville Pike, Rockville, Maryland 20852-2738 (axa@nrc.gov).

22. Lloyd Jollay, BWXT/Y-12, Y-12 National Security Complex, P.O. Box 2009, Oak Ridge, TN 37831-8245 (jollayl@y12.doe.gov).

23. R. A. Butler, Director, Research Reactor Center, 1513 Research Park Drive, Columbia, MO 65211 (ButlerRa@missouri.edu).

24. D. Chong, NA-212, U.S. Department of Energy, 1000 Independence Avenue SW, Washington, DC 20585 (Daniel.Chong@nnsa.doe.gov).

25. Peter Lee, Office of Basic Energy Sciences, U.S. Department of Energy, 1000 Independence Avenue SW, Washington, DC 20585 (Peter.Lee@science.doe.gov).

26. Van Nguyen, Office of Basic Energy Sciences, U.S. Department of Energy, 1000 Independence Avenue SW, Washington, DC 20585 (van.nguyen@science.doe.gov).

27. Tony Vinnola, INL, P.O. Box 1625, MS 3860, Idaho Falls, ID 83415-3860 (anthony.vinnola@inl.gov).

28. David McDaniel, INL, P.O. Box 1625, MS 3860, Idaho Falls, ID 83415-3860 (David.McDaniel@inl.gov ).

29. Sean O’Kelly, NIST Center for Neutron Research, 100 Bureau Drive, Stop 8560, Gaithersburg, MD 208998560 (sean.okelly@nist.gov).

30. Chris Landers, NA-212, U.S. Department of Energy, 1000 Independence Avenue SW, Washington, DC 20585 (christopher.landers@nnsa.doe.gov).

31. Jeff Chamberlin, NA-212, U.S. Department of Energy, 1000 Independence Avenue SW, Washington, DC 20585 (jeffry.chamberlin@nnsa.doe.gov).

32. C. McKibben, University of Missouri Research Reactor Facility, Columbia, MO 65211 (mckibben@missouri.edu).

33. D. M. Hewitt, Idaho National Laboratory, P.O. Box 1625, Idaho Falls, ID 83415-3750 (Dana.Hewitt@inl.gov).

34. T. Newton, MIT Nuclear Reactor Laboratory, 138 Albany St., Cambridge, MA 02139 (tnewton@mit.edu).

35. W. Richards, NIST Center for Neutron Research, 100 Bureau Drive, Stop 8561, Gaithersburg, MD 208998561 (wade.richards@nist.gov).

36. W. C. Richardson, BWXT Technology, Inc., 2016 Mount Athos Rd., Lynchburg, VA 24504 (WCRichardson@bwxt.com).

37. J. Roglans, Argonne National Laboratory, 9700 S. Cass Avenue, Argonne, IL 60439 (roglans@anl.gov).

38. J. Snelgrove, Argonne National Laboratory, 9700 S. Cass Avenue, Argonne, IL 60439 (jimsnelgrove@anl.gov).

39. P. Staples, NA-212, U.S. Department of Energy, 1000 Independence Avenue SW, Washington, DC 20585 (Parrish.Staples@nnsa.doe.gov).

40. Daniel M. Wachs, MFC 791 B-147, Idaho National Laboratory, P.O. Box 6188, Idaho Falls, ID 83415 (Daniel.Wachs@inl.gov ).

41. R. E. Williams, NIST Center for Neutron Research, 100 Bureau Drive, Stop 8560, Gaithersburg, MD 208998560 (robert.williams@nist.gov).

42. John Stevens, Argonne National Laboratory, 9700 S. Cass Avenue, Argonne, IL 60439 (johnstevens@anl.gov)

43. Eric C Woolstenhulme, P.O. Box 1625, Idaho Falls, ID 83415-3750 (Eric.Woolstenhulme@inl.gov).

44. Pedro Mantano, Office of Basic Energy Sciences, U.S. Department of Energy, 1000 Independence Avenue SW, Washington, DC 20585 (pedro.montano@science.doe.gov).

45. Carol Sohn, of Basic Energy Sciences, U.S. Department of Energy (carol.sohn@pnso.science.doe.gov). 
46. Johnny O. Moore, U. S. Department of Energy, (moorejo@ornl.gov).

47. John Ritchie, International Nuclear Enterprise Group, LLC, 11474 N Verch Way, Tucson AZ, Suite 100 85737, (john@nuclearenterprises.com) 